\title{
Standartlaştırılmış Yağış İndisi (SYİ) Yöntemi ile Şanlıurfa İli Kuraklık Analizi*
}

\section{Drought Analysis of the Şanluurfa Province Using the Standardized Precipitation Index (SPI) Method}

\author{
Mustafa Recep İRCAN ${ }^{1}$ (อ, Neşe DUMAN² (1)
}

${ }^{1}$ Yüksek Lisans, Çankırı Karatekin Üniversitesi, Sosyal Bilimler Enstitüsü, Çankırı, Türkiye

${ }^{2}$ Dr. Öğr. Üyesi, Çankırı Karatekin Üniversitesi, Edebiyat Fakültesi, Coğrafya Bölümü, Çankırı, Türkiye

ORCID: M.R.İ. 0000-0002-3787-7688; N.D. 0000-0002-5398-8388

\section{öz}

Kuraklık, su bütçesinin belirli bir alanda ve zamanda negatif değerler göstermesi olarak tanımlanmaktadır. Karmaşık süreçlerle gelişmesi, sinsi ve yavaş süreçlerin ürünü olması, kuraklığın diğer afetlerden farkını ortaya koymaktadır. Yeryüzünde meydana gelen kuraklıklar, planlaması yapılamadığı takdirde çok boyutlu afet özelliği kazanarak canlı yaşamını tümüyle etkileyebilmektedir. Kuraklığın meteorolojik boyutuyla alakalı hazırlanan bu çalışmada, Şanlıurfa ilinin kuraklık özelliği ele alınmıştır. Kuraklık analizinde Standartlaştırılmış Yağış İndisi (SYi) 12 aylık zaman serisi halinde analiz edilmiştir. SYi yönteminde kullanılan tek meteorolojik değişkenin yağış olması nedeniyle Şanlıurfa ilindeki 5 istasyonun (Şanlıurfa merkez, Akçakale, Birecik, Ceylanpınar ve Siverek) 1975-2019 yılları arasındaki yağış verileri kullanılmıştır. Kuraklığın süresindeki ve sıklığındaki artışın daha iyi anlaşılması için analiz sonuçları iki dönem (19751997 ile 1997-2019) halinde incelenmiştir. Elde edilen bulgulara göre, Şanlıurfa merkez ile Siverek istasyonlarında kurak dönemlerin oranı nemli dönemlere oranla fazla iken; Akçakale, Birecik ve Ceylanpınar istasyonlarındaki nemli dönemlerin oranının kurak dönemlere oranla daha fazla olduğu tespit edilmiştir. Bunun yanı sıra kurak dönemlerin zamana bağlı gösterdiği gidişlere bakıldığında, sahadaki tüm istasyonlarda I. dönemdeki kuraklıkların şiddeti, sıklığı ve süresinin II. Dönemde önemli oranda artışlar gösterdiği tespit edilmiştir. Bu durum, kurak-yarı kurak iklim özelliğine sahip araştırma sahasının kuraklığa karşı hassasiyetini ve etkilenebilirliğini ortaya koymaktadır.

Anahtar kelimeler: Şanlıurfa, kuraklık analizi, Standartlaştırılmış Yağış İndisi (SYi)

\section{ABSTRACT}

Droughts are typically defined by negative water budget values in a certain area and time. The development of complex processes and product of insidious and slow processes reveal the difference of drought from other disasters. Droughts occurring on Earth can become multidimensional disasters and affect life completely if not planned and prepared for. In this study on the meteorological dimensions of drought, the drought characteristics of the province of Şanlıurfa are discussed. The standardized precipitation index was analyzed in a 12-month time series in the drought analysis. Because precipitation is the only meteorological variable used in the SPI method, the rainfall data of five stations (Şanlıurfa center, Akçakale, Birecik, Ceylanpınar, and Siverek) between 1975 and 2019 in Şanlıurfa were used. Analysis results were examined in two periods (1975-1997 and 1997-2019) to better understand the increase in drought duration and frequency. The results show that the rates of dry periods in Sanliurfa center and Siverek stations are higher than those of humid periods. It was determined that the rates of humid periods in Akçakale, Birecik, and Ceylanpınar stations are higher than those of dry periods. Moreover, dry periods have increased significantly during the first period considering their trends depending on time, severity, frequency, and the duration of droughts at all stations in the field. This situation reveals the susceptibility and vulnerability of the research area to arid-semiarid climates.

Keywords: Drought analysis, Şanlıurfa, standardized precipitation index (SPI)

*Bu çalışma, Mustafa Recep IRCAN’ın Neşe DUMAN danışmanlığında hazırladığı "Şanlıurfa'nın Iklim Özellikleri ve Kuraklık Analizi” başlıklı yüksek lisans tezinin bir bölümünden üretilmiştir.

Başvuru/Submitted: 11.10.2019 • Revizyon Talebi/Revision Requested: 20.11.2019 • Son Revizyon/Last Revision Received: 05.06 .2020 • Kabul/Accepted: 08.06.2020 • Online Yayın/Published Online: 28.05.2021

Sorumlu yazar/Corresponding author: Mustafa Recep IRCAN / mustafarecepircan@gmail.com Atıf/Citation: Ircan, M. R., \& Duman, N. (2021). Standartlaştırılmış Yağış İndisi (SYi) Yöntemi ile Şanlıurfa ili kuraklık analizi. Cografya Dergisi, 42, 1-18. https://doi.org/10.26650/JGEOG2020-0070 


\section{EXTENDED ABSTRACT}

Drought is a multidimensional climatic process that occurs when the water budget shows negative values within spatial and temporal bases. Underlying the multidimensional nature of droughts is the fact that climate affects all aspects of life. Drought is an important natural disaster that develops slowly and insidiously and negatively affects the life triangle formed by air, water, and soil in the region where it is effective. The difference of drought from other natural disasters is that it is a complex and least comprehensible chain of processes affecting more people.

Drought is classified as meteorological, agricultural, hydrological, and socioeconomic (Figure 1). Meteorological drought occurs when precipitation falls below average. Agricultural drought occurs when plants cannot meet their water needs from the soil in a certain period. Hydrological drought arises with a lack of underground and surface water resources. Moreover, socioeconomic drought comes to the fore with the food crisis experienced after other droughts.

In this study on the meteorological dimensions of droughts, the drought characteristics of Şanlıurfa are discussed. The standardized precipitation index (SPI) was analyzed in a 12-month time series in the drought analysis. The only meteorological variable used in this method is rainfall; therefore, only rainfall data were used in the drought analysis of the area.

This method is one of the most important drought analysis methods for determining drought and wetness periods depending on rainfall changes on long time scales. Precipitation can be measured at 1, 3, 6, 12, 24, and 48 months using rainfalls of at least 30 years. It is obtained by dividing the difference of precipitation from the mean by the standard deviation in a time series (Formula 1). A time period in which index values are constantly negative is defined as a dry period. The month in which the value falls below zero is considered the beginning of a drought, whereas the month when the index rises to positive values is considered the end of a drought (Figure 5).

According to the analysis results, although more dry periods occurred in Şanliurfa center and Siverek stations than humid periods (Figures 6 and 14), more humid periods occurred than dry periods in Akçakale, Birecik, and Ceylanpınar stations (Figures 8, 10, and 12). Especially in the 45-year period compared with the first period, it was observed that drought severity, duration, and frequency increased in all stations except in Siverek during the second period (Figures 7, 9, 11, and 13). Results similar to those of other studies prepared in different time frames and different time series were obtained. Except for the last 2 years, the droughts seen in the previous 10 years were caused by the lack of rainfall in the field. In the application of the 12-month period in the research area, the high precipitation variation coefficients of all other stations except Siverek caused the dry and humid periods to persist in long periods. In the Siverek station, the high precipitation values and standard deviation and low rainfall variation coefficient resulted in alternating dry and humid periods in the SPI.

The increase in dry periods in recent years reveals the necessity of multidirectional action plans related to drought. In this regard, the physical geographic conditions (climate, hydrography, and hydroclimatology) of the research area should first be well understood, and sustainable and applicable studies should be planned in all the known aspects. The existence of fertile plains in the field reveals that regular and sustainable hydroclimatic plans should be made to minimize the effect of drought on agricultural activities. Particular attention should be paid to studies on the climate and drought characteristics of Şanlıurfa, and forward-looking policies should be developed and put into action, taking into account the results of these and similar studies. 


\section{GÍRIŞ}

Küresel 1sınmaya bağlı olarak gerçekleşen iklim değişikliği, insanlığın karşılaştığı en büyük sorunlar arasında yer almaktadır. Sıcaklıkların artması ve düzensiz yağış rejimlerine bağlı yaşanan kuraklıklar, iklim değişikliğinin en önemli sorunlarından biridir (Karaer ve Gültaş, 2018: 303). Tanımı itibariyle kuraklık, su bütçesinin alansal ve zamansal kaideler içerisinde negatif değerler göstermesiyle meydana gelen çok boyutlu klimatik süreçtir. Kuraklığın çok boyutlu oluşunun temelinde, iklimin canlı yaşamının her alanında etkin olması, faktörü yer almaktadır (İrcan, 2020: 7). Çünkü kuraklık, etkilediği bölgedeki hava, su ve toprağın oluşturduğu yaşam üçgeni üzerinde çok olumsuz sonuçlar bırakan, yavaş ve sinsice gelişen önemli bir doğal felakettir. Kuraklığın diğer doğal felaketlerden farkı, daha fazla insanı etkileyerek karmaşı ve en az anlaşılabilen süreçler zinciri olmasıdır. Yıkıcı sonuçlara sahip olan kuraklığın başlangıcını kesinlikle tanımlamak mümkün değildir (Sırdaş, 2002: 5). Kademeli bir olgu olup, kısa süreli oluşabildiği gibi yıllarca da sürebilmektedir (Karaer ve Gültaş, 2018: 303).

Çeşitleri itibariyle kuraklık; meteorolojik, tarımsal, hidrolojik ve sosyoekonomik olarak sinıflandırılmaktadır (Şekil 1). Meteorolojik kuraklık, yağışın ortalamanın altına düşmesiyle; tarımsal kuraklık, belirli zaman periyodunda bitkinin ihtiyacı olan suyu topraktan karşılayamamasıyla; hidrolojik kuraklık yeraltı ve yerüstündeki su kaynaklarının eksikliğiyle; sosyoekonomik kuraklık ise diğer kuraklıklar sonrası yaşanan gıda kriziyle meydana gelmektedir. Sırdaş (2002: 7), sosyoekonomik kuraklığ 1 ekonomik mallardaki arz ve talep durumu olarak nitelendirmektedir.

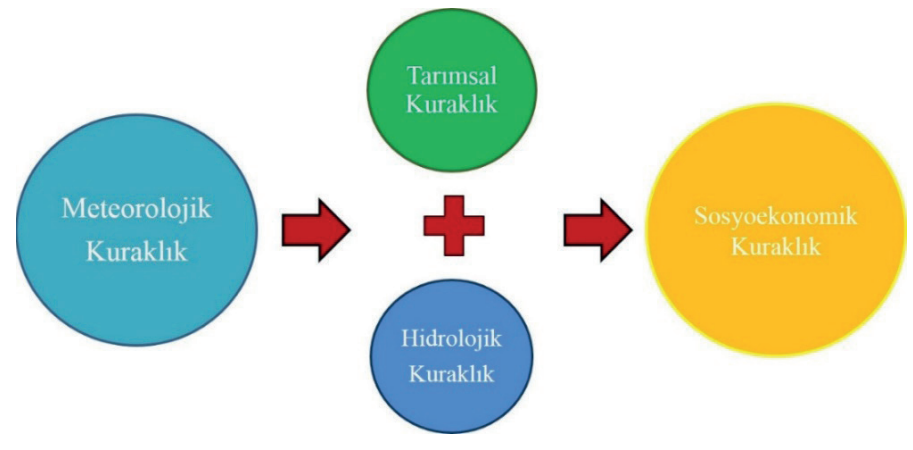

Şekil 1: Kuraklık Çeşitleri.

Figure 1: Types of Drought.

Meteorolojik olarak yaşanan kuraklıklar, önlemi alınamadığı takdirde kelebek etkisi yaparak afet niteliği kazanıp, önemli sorunları beraberinde getirebilmektedir! $\mathrm{Bu}$ durum özellikle yılın büyük kısmını kurak geçiren karasal antisiklon ve onun çevresindeki sahalar için önemli riskler teşkil etmektedir.
Kuraklık, kurak ve yarı kurak bölgelerin yanı sıra orta enlemlerin nemli-denizel iklimleri gibi diğer iklim bölgelerinde de meydana gelebilir (Türkeş 1999; Türkeş ve Tatl1, 2010: 246).

Kuraklığa neden olan süreçler, fiziksel, sinoptik ve istatistiksel açıdan incelendiğinde, karmaşık ve tam olarak anlaşılamayan (Sırdaş, 2002: 5; Türkeş ve Tatll, 2010: 246) birtakım mekanizmalar tarafından denetlendiği görülmektedir (Yetmen, 2013b: 35). Bu durumun troposferde dinamik ya da termik nedenlerle gelişen bir antisiklon çekirdeğine bağlı olarak sürekli ya da kısmen gelişebildiği gibi, yörenin fiziki coğrafya değişkenlerine (yükselti, bakı, denizellik-karasallık, orografik şartlar vs.) bağlı olarak da gerçekleşebildiği söylenebilir. Antisiklon sahalar ile bu sahaların mevsimsel olarak hakimiyet sahasını genişletmesiyle ortaya çıkan kurak-yarı kurak sahalar, atmosferdeki genel sirkülasyon mekanizmasıyla açıklanmaktadır. Özellikle, Türkiye ölçeğinde kış ve bahar mevsimlerinde görülen kuraklıklar, Anadolu ve Akdeniz çevresinde etkili olan termik ve subtropikal yüksek basınç merkezleriyle (Türkeş, 1990); yaz mevsiminde meydana gelen kuraklıklar, Azor yüksek basıncının kuzeye doğru ilerlemesiyle Akdeniz Havzası'nın, Tropikal hava kütlesinin etkisi altına kalmasıyla yani cephesel sistemlere bağlı yağış oluşumunun ortadan kalkmasıyla meydana gelir (Çiçek ve Ataol, 2009; Türkeş, 1990). Kışın, İç, Doğu ve Güneydoğu Anadolu Bölgelerinde egemen olan Antisiklon, karasallığın da etkisiyle daha da güçlenerek bu dönemde yağış azlığı üzerinde etkili olmaktadır (Koçman, 1993: 83).

Ayrıca, atmosfer ile okyanus arasındaki etkileşime bağlı, birbirine uzak alanlardaki iklim anomalilerinde zit karakterli meydana gelen değişimler olarak bilinen teleconnection (uzakbağlantı) mekanizması (Hurrell \& Van Loon, 1997; Hurrell vd., 2003) (ör.: Kuzey Atlantik Salınımı, El Niño-Güney Salınımı, Arktik Salınım), dünya üzerinde dönemsel olarak meydana gelen kuraklıkların oluşumuna neden olabilmektedir. Bunlardan Kuzey Atlantik Salınımı'nın (KAS), pozitif olduğu dönemde Azor üzerindeki basınç değerleri normal seviyesinden daha yüksek seyrederek (bu dönemde İzlanda'nın basınç değeri ise normalin altındadır), Akdeniz Havzası başta olmak üzere Grönland ve Kanada'nın doğusunun, batı rüzgarlarının taşıdığı nemli hava kütlesinden mahrum kalmasına yol açarak, bu dönemdeki kuraklıkların yaşanmasına neden olur (Yetmen, 2013b: 111). Türkiye'nin yağış parametreleri üzerinde önemli etkileri bulunan KAS'ın kuvvetli pozitif olduğu, 1983-1984, 1988-1989, 1990, 1992, 1994-1995, 1998-2000 y1lları (Erlat, 2002; Hizarcıoğlu, 2010: 16; Türkeş ve Erlat, 2003: 330; Yetmen, 2013b: 113; Yetmen, 2014: 92) aynı zamanda yağış değerlerinin düşük olduğu $(\mathrm{Bu}$ dönemlerin, araştırma sahasındaki yağış 
değerleri (İrcan, 2020: 68-76) ile yapılan SYİ analizinde kurak dönemlere karşıllk geldiği (Gümüş vd., 2016: 39-40; İrcan, 2020: 125-131; Kızılelma ve Karabulut, 1147-1148; Yetmen vd., 2017: 140) görülmektedir.) döneme denk gelmektedir. Her ne kadar KAS ile yağışa bağlı yaşanan kuraklık arasında sıkı bir ilişki olsa da Türkiye'deki yağışlar üzerinde etkili olan tek faktörün KAS olmayıp, yağışı etkileyen faktörler arasında çeşitli Planeter (Genel atmosfer sirkülasyonu ve hava kütleleri) ve coğrafi faktörlerin (yükselti, bakı, denizellik-karasallık, orografik şartlar vs.) bulunduğu bilinmektedir. Tüm bunlar, yağış azlığına bağlı kuraklıkların yaşanmasına neden olur.

Dünyanın birçok sahasında görülebilmesi ve karmaşık atmosferik süreçlerle insan yaşamını olumsuz etkilemesi nedeniyle kuraklığ 1 incelemek ve izlemek için çeşitli indisler geliştirilmiştir. Bunlardan en çok bilinen ve kullanılanları, Palmer Kuraklık Şiddet İndisi (PDSI) (Palmer, 1965) ve Standartlaştırılmış Yağış İndisi (SYI)'dir (McKee vd., 1993, 1995). Bu ve buna benzer kuraklık indisleriyle yapılan analizler sayesinde kuraklıkların zamana ve mekâna bağlı olarak belirlenip, izlenmesi ve değerlendirilmesi yapılmaktadır. Yani konuyla alakalı risk durumları belirlenip kriz öncesi planların yapılması sağlanabilmektedir.

Dünyada ve Türkiye'de Standartlaştırılmış Yağış İndisi (İng.: Standard Precipitation Index-SPI), kullanılarak birçok çalışma yapılmıştır. Dünya'da SYİ üzerine hazırlanan bazı çalışmalar sırasıyla şu şekildedir: Edwards (1997), ABD'deki; Moreira vd. (2006), Alentejo Bölgesi'ndeki (Portekiz); Patel vd. (2007), Hindistan'daki; L1 vd. (2008), Güney Amazon'daki; Fathabadi vd., (2009) İran'daki; Chen vd. (2009) Tayvan'daki; Kim vd. (2009), Güney Kore'deki; Santos vd. (2011) Portekiz'deki; Zhang vd. (2012) Çin'deki; Di Lena (2013), Orta İtalya'daki; Liu (2013), Nanjing bölgesindeki (Çin); Gocic ve Trajkovic (2014), Sirbistan'daki; Guhathakurta vd. (2017), Hindistan'daki; Labedzki (2017) ise Polanya' daki çalışmalarla SYI'nin zamansal ve alansal olarak kuraklık durumlarını değerlendirmiş̧lerdir.

Türkiye'de hazırlanan kuraklık çalışmalarında da SYİ analiz modeli sıcça kullanılan yöntemlerden biridir. Sırdaş (2002), Türkiye'nin farklı bölgelerindeki 60 istasyonun meteorolojik kuraklığını belirlemek için SYİ'den yararlanmıştır. Bunun için 1930-1990 yılları arasındaki verileri kullanmıştır. SYİye ilaveten yeni bir yaklaşım olarak kuraklık oranı $(\mathrm{KO})$ yaklaşımını geliştirmiştir. Kuraklık analizi ve bazı kesim seviyeleri için kuraklık süresi, genliği ve şiddetini hesaplamıştır. Kömüşçü vd. (2003), Türkiye'deki 102 istasyonun uzun süreli yağış verilerini SYİ yöntemini kullanarak analiz etmiştir. Kuraklığın süresi ve şiddetinin Türkiye'nin hangi bölgelerinde etkili olduğunu belirlemiştir. Pamuk vd. (2004), Ege bölgesindeki kuraklıkları SYİ yöntemiyle incelemiştir. Elde edilen SYİ değerlerinin ortalama, maksimum, minimum ve standart sapma değerlerini ele almıştır. Ege Bölgesi'nin aylık ortalama SYİ değerlerinde yaz mevsimi de dahil olmak üzere kuraklık sınırında bir bulguya rastlanmadığını tespit etmiştir. Topçuoğlu vd. (2008), Ege bölgesindeki kuraklıkları, SYİ yöntemiyle 1, 3 ve 12 aylık zaman periyotlarında analiz etmişlerdir. 1977, 1989, 1990 ve 1992 yıllarında kuraklıkların yaşandığını gözlemlemiştir. Ayrıca kıyı bölgelerdeki kuraklığın daha şiddetli hissedildiğini tespit etmiştir. Türkeş ve Tatlı (2008). Türkiye'deki kuraklıkların alansal ve zamansal desenlerini, şiddeti ve sıklı̆g 1 gibi farklı yönlerini incelemek amacıyla yeni SYİyi kullanmışlardır. Sonuç olarak, yeni SYİ yönteminin Akdeniz iklim bölgesi gibi yağışların yüksek oranda değişkenlik gösterdiği ve diğer yarı kurak, kurak-yarı nemli ya da yarı nemli iklim bölgelerindeki kuraklıkların belirlenmesi ve izlenmesinde de kullanılabileceği sonucuna varmışlardır. Ilgar (2010), Çanakkale'nin 1929-2007 yılları arasındaki yağış verilerini kullanarak kuraklık analizini yapmıştır. Yöntem olarak SYİyi 3 aylık ve 12 aylık periyotlar halinde incelemiştir. Analizin sonuçlarına göre Çanakkale'de yıllık kuraklık koşullarında artış, ilkbahar kuraklığında azalma, yaz ve sonbahar kuraklıklarında ise çok belirgin olmayan artışların yaşandığını tespit etmiştir. Kızılelma ve Karabulut (2011), Şanlıurfa merkez, Akçakale, Birecik, Ceylanpınar ve Siverek'in 1975-2010 iklim verilerini, Thornthwaite iklim sınıflandırması, Erinç, SYİ ve Birleşmiş Milletler Çölleşme ile Savaşım Sözleşmesi kuraklık indislerini kullanarak incelemiş̧ir. Çalışmanın sonuçlarına göre kullanılan metot sonuçlarının benzerlik gösterip, günümüze yakın yıllarda kuraklığın etkisini giderek arttırdığını ve sahanın çölleşme süreçlerine açık olduğunu tespit etmiştir. Özellikle elde edilen SYİ değerleriyle alakalı SYI'deki negatif değerlerin günümüze yakın yıllarda yoğunlaştığını tespit etmiş̧tir. Kıymaz vd. (2011), SYİ yöntemiyle Seyfe'deki kuraklık oluşumlarını incelemiştir. 1975-2008 yıllarını 1.Dönem-2.Dönem halinde analiz etmiştir. Şiddetli ve çok şiddetli kuraklık oluşumlarının her iki dönemde de kısa ve uzun dönemler için minimum değerler gösterdiği sonucuna ulaşmış ve hafif kuraklıkların tüm zaman periyotlarında 2 . Dönemde arttığını tespit etmiştir. Yetmen (2013a), Van Gölü Havzası'ndaki kuraklıkları SYİ yöntemiyle incelemiştir. Ayrıca kurak dönemlerin Kuzey Atlantik Salınımı (KAS) indeksleriyle ilgisini Pearson korelasyon katsayısıyla belirlemiştir. Yetmen (2013b), çalışmasında Türkiye'nin kuraklık analizini SYİ metoduyla incelemiştir. Kuraklığın olasılığı ve süresi üzerinde durduğu gibi kuraklığın şiddetini ve genliğini de SYİye göre açıklamıştır. Ayrıca, KAS'ın nemlilik ve kuraklık üzerindeki 
etkisine de değinerek, KAS indeksleri ile SYİ serilerinin korelasyonunu, hazırlanan haritalar yardımıyla açıklamıştır. Dinç vd. (2016), SYİ yöntemiyle Antalya ilindeki istasyonların 1970-2014 yağış verilerini kullanılarak kuraklık analizini yapmıştır. SYİ yöntemini 3, 6, 12 ve 24 aylık dönemler halinde incelemiştir. Buna göre SYİ değerlerinde bir azalma olmadığını, değerlerin normale yakın kurak değerleri arasında yer aldığını tespit etmiştir. Gümüş vd. (2016), Şanlıurfa merkezin 78 yıllık (1937-2014) yağış verilerini kullanarak kuraklık analizini yapmıştır. Kuraklığın belirlenmesinde SYİ yöntemini 1, 3, 6 ve 12 aylık zaman periyotları halinde incelmiştir. Çalışmanın sonucunda, 1986-2014 yılları (29 yıl) arasındaki aşırı kurak geçen ay sayısının, 1937-1985 yılları (49 yıl) arasındaki kurak geçen ay sayısından daha fazla olduğunu tespit etmiştir. Yetmen vd. (2017), Harran Ovası'ndaki kuraklı̆̆ı SYİ ve Thornthwaite yöntemiyle uzakbağlantı (teleconnection) ilişkilerini incelemiştir. Çalışmanın sonuçlarına göre ovanın kuzeyindeki kuraklıklar, ovanın güneyine göre daha geç başlamakta ve daha kısa sürmektedir. Ayrıca kurak dönemlerin süresi ve şiddetinin birbirinden farklı olduğu iki dönem (1975-1999 ile 1999-2012 yılları) saptamıştır. Kurak dönemlerin süresinin ve şiddetinin, ikinci dönemde belirgin biçimde küresel iklim değişikliği ile ilgili olduğu düşünülen artışlar gösterdiğini tespit etmiştir. Karaer ve Gültaş (2018), Birecik'in 1980-2014 yılları arasındaki uzun süreli yağış verilerini çeşitli periyotlar halinde SYİ yöntemini kullanarak kuraklık analiz etmiştir. Analiz sonucunda kuraklıkların en fazla 6 ve 12 aylık zaman periyotlarında hissedildiğini tespit etmiştir. İrcan (2020), çalışmasında Şanlıurfa'nın iklimi ve kuraklık analizini Thornthwaite ve De Martonne iklim sınıflandırması, SYİ, Erinç ve UNCCD kuraklık analizi yöntemleriyle incelemiştir. Tüm sınıflandırma metotlarında sahanın kuzeyinden güneyine doğru kuraklıkların arttığını ve sahanın kuraklığa karşı hassas ve kırılgan bir yapıda olduğunu tespit etmiştir. Analizlerde kullandığı metot sonuçlarının benzerlik gösterdiğini, günümüze yakın yıllarda kuraklığın etkisini giderek arttırdığını ve sahadaki istasyonların çölleşme süreçlerine açı olduğunu tespit etmiştir. Ayrıca son yıllarda kuraklıktaki artışın ve meteorolojik değişkenlerde görülen dengesizliğin küresel iklim değişikliğiyle alakalı olduğunu öngörmüştür.

$\mathrm{Bu}$ çalışmada Şanlıurfa ilindeki beş istasyonun (Şanlıurfa merkez, Akçakale, Birecik, Ceylanpınar ve Siverek) nemlilik ve kuraklık durumları ele alınmıştır. Araştırma sahası olarak Şanlıurfa ilinin incelenme nedeni, araştırma sahasının sıcaklık değerlerinin yüksek, yağış değerlerinin ise düşük olmasıdır. Özellikle yaşanan iklim değişikliği ile meteorolojik ölçümlerde yaşanan ekstrem durumlar, kurak-yarı kurak iklim özelliklerine sahip (Aydın vd., 2019; Bölük, 2016; İrcan, 2020; Kızılelma ve Karabulut, 2011; Türkeş, 1990; Yılmaz ve Çiçek, 2016; Yetmen vd., 2017) Şanlıurfa ilinin bu özelliği onun kuraklık açısından kırılgan bir özellik göstermesine neden olmuştur. Çalışmanın ilk bölümünde araştırma sahasının konumu ve genel coğrafi özellikleri hakkında bilgiler verilmiştir. İkinci bölümde kullanılan yöntem ve materyal açıklanmıştır. Üçüncü bölümde elde edilen bulgular istasyon ölçeğinde yorumlanmıştır. Son bölümde ise elde edilen bulgular genel bir değerlendirme ile ele alınıp önerilerde bulunulmuştur.

\subsection{Araştırma Sahasının Konumu ve Genel Coğrafi Özelliği}

Şanlıurfa ili Türkiye'nin güneydoğusunda, 3749'12"'$40^{\circ} 10^{\prime} 00^{\prime \prime}$ doğu boylamları ile $36^{\circ} 41^{\prime} 28^{\prime \prime}-37^{\circ} 57^{\prime} 50^{\prime \prime}$ kuzey enlemleri arasında yer almaktadır. Sahanın doğusunda Mardin, batısında Gaziantep, kuzeydoğusunda Diyarbakır, kuzeybatısında Adıyaman illeri bulunmaktadır. Güneyde Türkiye-Suriye kara sınırı oluşturan Suriye bulunmaktadır. İlin ortama yükseltisi 500 metrenin üzerinde olup yüzölçümü $18.765 \mathrm{~km}^{2}$ 'dir. Araştırma sahasının morfolojik durumu, kuzeyden güneye doğru alçalan basamaklı topoğrafya yüzeyi olarak kendini göstermektedir. Bu topoğrafya yüzeyi genel olarak yükseltisi fazla olmayan, sade düzlüklerden oluşmaktadır (Şekil 2). Topoğrafya yüzeyinin basamaklı özellik göstermesi, sıcaklık ve yağış değerlerinde farklıklara neden olmuştur. Ortalama sıcaklık değerleri kuzeyden güneye doğru artarken, yağış miktarları aynı yönde azalmaktadır (Şekil 2 ve 3).

Araştırma sahasındaki istasyonların uzun yıllık sicaklık ve yağış değerleri sırasıyla şu şekildedir: Uzun yıllık ortalama sıcaklıkları, Şanlıurfa merkezde $18,5^{\circ} \mathrm{C}$; Akçakale'de $18,3^{\circ} \mathrm{C}$; Ceylanpınar'da $18,2^{\circ} \mathrm{C}$; Birecik'te $17,8^{\circ} \mathrm{C}$; Siverek'te $16,6^{\circ} \mathrm{C}$ 'dir (Şekil 3).

Uzun yıllık yağış ortalamaları, Siverek'te $569,1 \mathrm{~mm}$; Şanlıurfa merkezde 459,8; Birecik'te 375,5 mm; Ceylanpınar'da 312 mm; Akçakale'de 291,5 mm'dir (Şekil 4).

\section{MATERYAL VE YÖNTEM}

Çalışmada kullanılan veriler, 1975-2019 yıllarını kapsamakta olup Şanlıurfa Meteoroloji Müdürlüğünden temin edilmiştir. Sahada 11 meteoroloji istasyonu bulunmaktadır. Ancak bu istasyonlardan bazılarının yakın zamanda kurulmuş olması (Halfeti, Harran ve Suruç), bazılarının ise 1975-2019 yılları arasında ölçüm eksikliğinin bulunması (Bozova, Hilvan ve Viranşehir), nedeniyle bu istasyonlar yapılan analizden muaf 


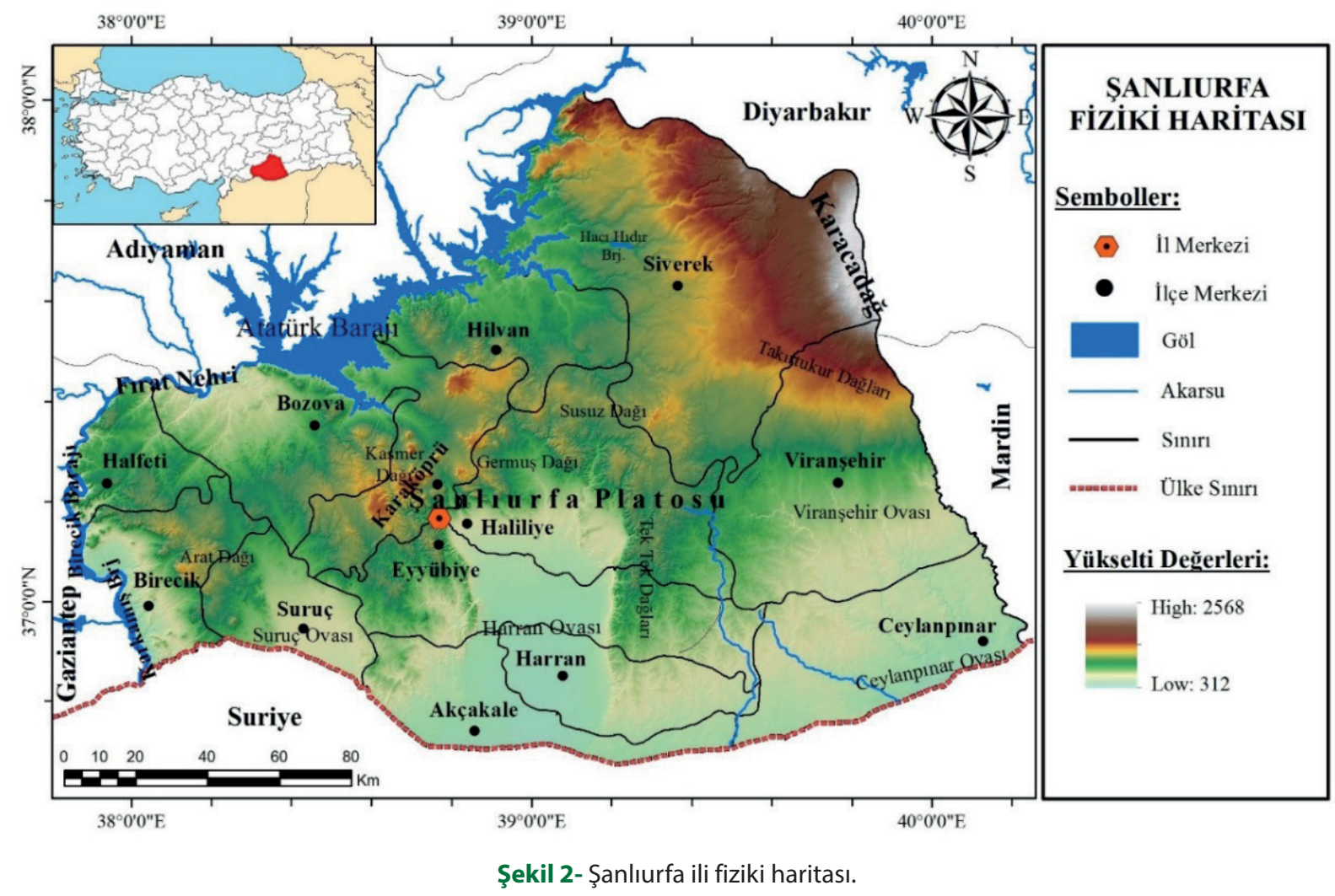

Figure 2: Physical map of Şanlıurfa province.

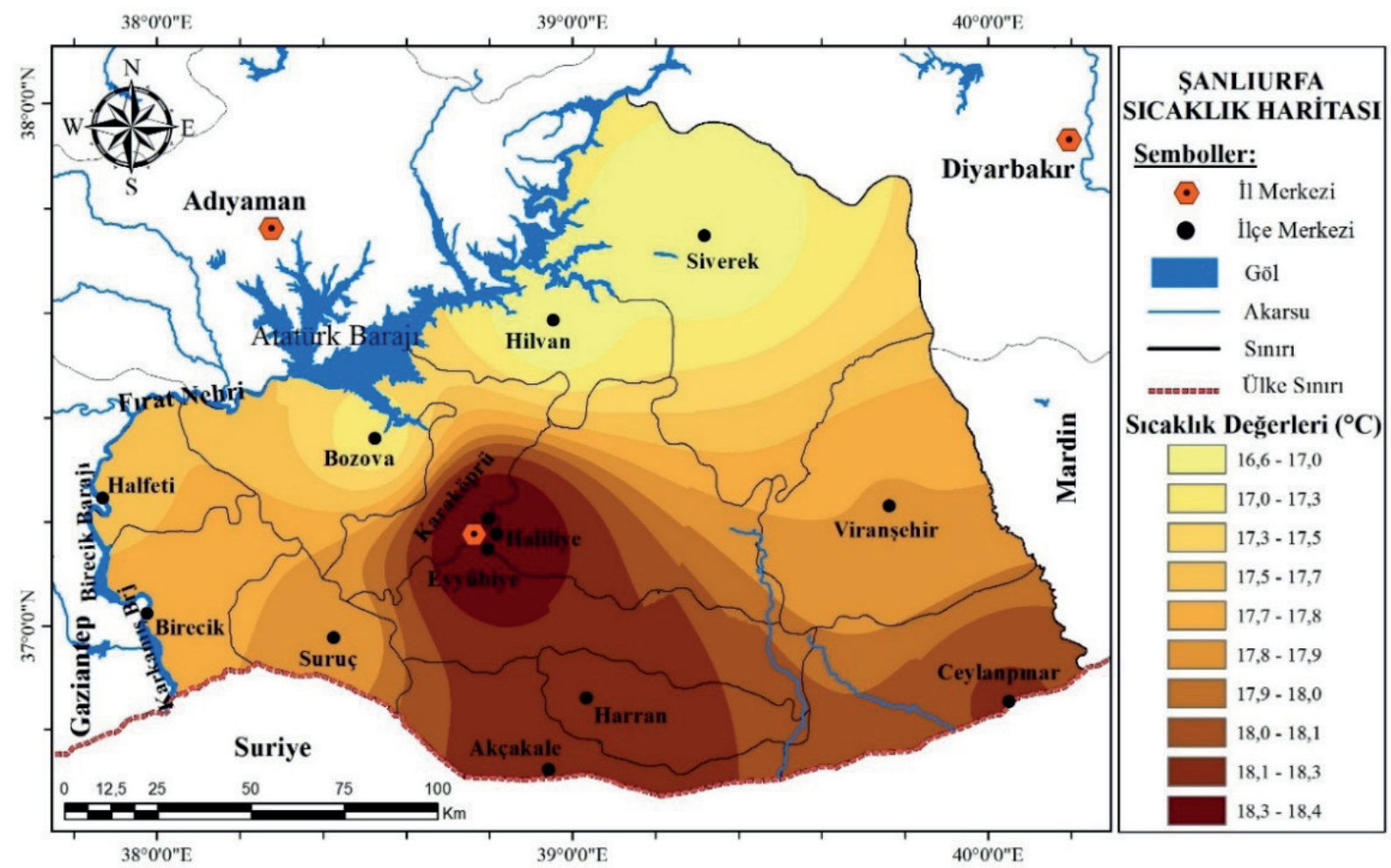

Şekil 3: Şanlıurfa ili sıcaklık haritası.

Figure 3: Temperature map of Şanlıurfa province. 


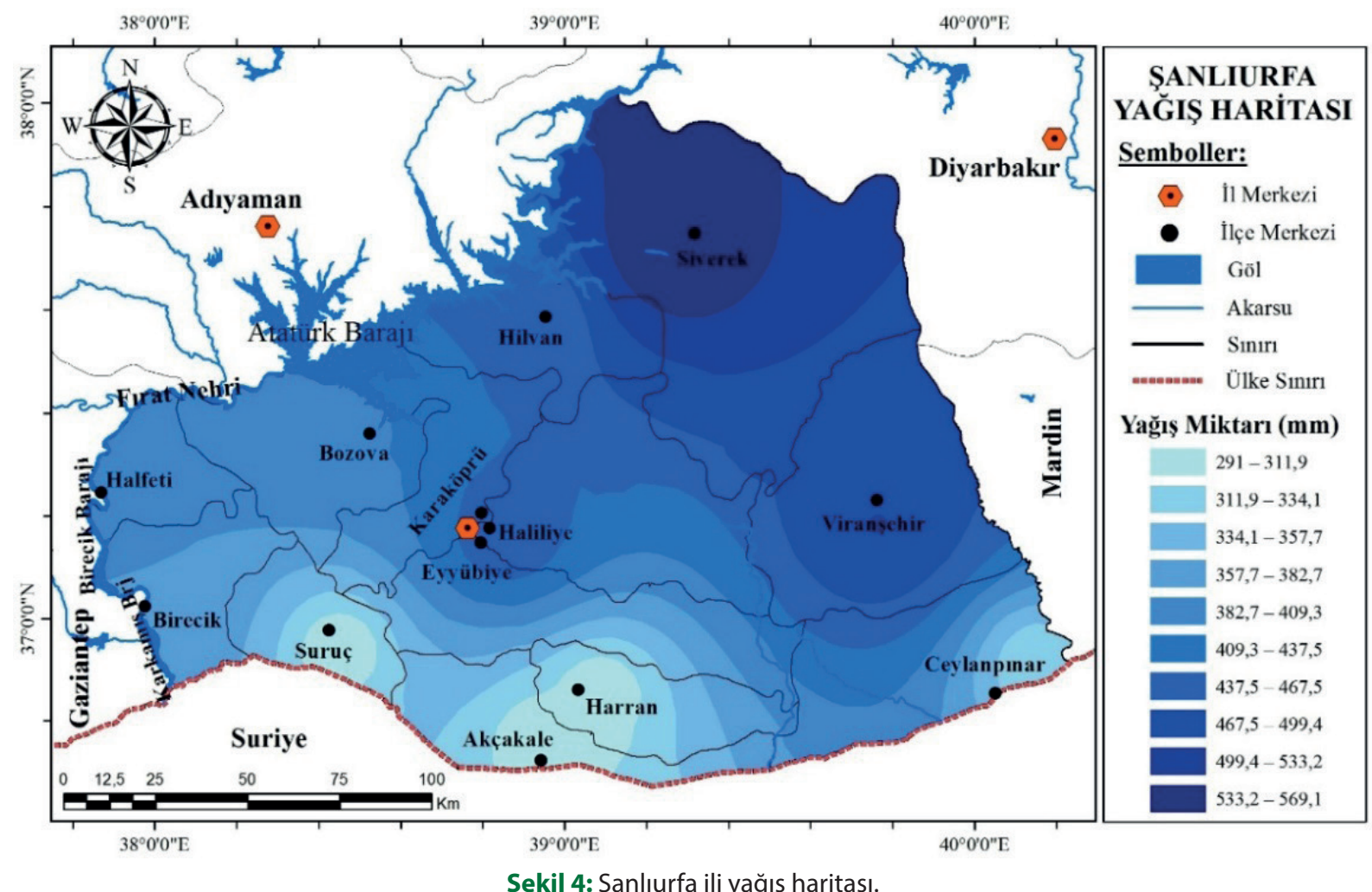

Şekil 4: Şanlıurfa ili yağış haritası.

Figure 4: Rainfall map of Şanlıurfa province.

tutularak yalnızca 5 meteoroloji istasyonun (Şanlıurfa merkez, Akçakale, Birecik, Ceylanpınar ve Siverek) yağı̧̧ değerleri ele alınmıştır. Araştırmada kullanılan kuraklık analiz yöntemi Standartlaştırılmış Yağış İndisi (SYİ, İng.: Standard Precipitation Index-SPI)'dir. $\mathrm{Bu}$ yöntemde kullanılan meteorolojik veri yağıştır. Bu nedenle sahanın kuraklık analizinde sadece yağış verileri kullanılmıştır.

\subsection{Standartlaştırılmış Yağıș İndisi (SYİ)}

Standartlaştırılmış Yağış İndisi, yapılan araştırmalarda sık kullanılan kuraklık analiz yöntemlerinden biridir. Bu yöntem, 1993 yılında Mckee, Doesken ve Kleist tarafından geliştirilmiştir. SYİ metodunda kullanılan tek meteorolojik veri yağıştır. Bu yöntem, uzun zaman ölçeğinde yağışlarda meydana gelen değişikliğe bağlı olarak, kuraklık ve nemlilik dönemlerinin belirlenmesi açısından önemli kuraklık analiz metotlarından biridir. En az 30 yıllık yağışlar kullanılarak, bu yağışların 1, 3, 6, 12, 24, 48 aylık vb. zaman serilerinde toplam yağışlar üzerinden yapılan işlemlerle veri çıktısı elde edilir. İndis değerlerinin sürekli olarak negatif olduğu zaman periyodu kurak dönem olarak tanımlanır. Değerin sıfır altına düştüğü ay kuraklığın başlangıcı olarak kabul edilirken, indisin pozitif değerlere yükseldiği ay kuraklığın bitimi olarak değerlendirilir (McKee vd., 1993). Tablo 1'deki sınıflandırmada normale yakın değer aralığında SYI'nin eksi değerlere düştüğü dönemler kurak dönem olarak tanımlanmaktadır. $\mathrm{Bu}$ sebeple bu çalışmada normale yakın sınıflandırmadaki eksi değerlere düşen dönemler, hafif kurak ya da normale yakın sınıftaki kuraklık anlamına gelen normale yakın kurak olarak tanımlanmıştır.

Formül 1'de belirtildiği gibi belirlenen zaman dilimlerinden $(1,3,6,12,24,48 \mathrm{vb}$. ay), yağışın ortalamadan olan farkının standart sapmaya bölünmesiyle elde edilir. Elde edilen sonuçların Tablo 1'daki değerlendirmeye göre nemlilik ve kuraklık durumları belirlenir:

Tablo 1: SYi değerlerinin kuraklık ve nemlilik derecelerine göre sınıflandırılması.

Table 1: Classification of SYI values according to drought and humidity levels.

\begin{tabular}{cc}
\hline SYi Değerleri & SYi Sınıflandırması \\
\hline$S Y i \mid \geq 2,00$ & Aşıı Nemli (extremely wet) \\
$1,99-1,50$ & Çok Nemli (very wet) \\
$1,49-1,00$ & Orta Düzeyde Nemli (moderately wet) \\
$0,99-(-0,99)$ & Normale Yakın (near normal) \\
$(-1,00)-(-1,49)$ & Orta Düzeyde Kurak (moderately dry) \\
$(-1,50)-(-1,99)$ & Şiddetli Kurak (severely dry) \\
$-2,00 \leq \mathrm{SY}$ & Aşırı Kurak (extremely dry) \\
\hline
\end{tabular}




$$
S Y \dot{I}=\frac{x_{\mathrm{i}}-\bar{X}_{\mathrm{i}}}{\sigma}
$$

SYI: Standartlaştırılmış yağış indisini, $x_{\mathrm{i}}$ : Aylık yağış miktarını, $\bar{X}$ : Uzun dönemli yağış ortalamasını, $\sigma$ : Uzun dönemli yağışlardaki standart sapmayı, ifade etmektedir.

SYİ değerlerinin hesaplanmasında; en az 30 yıllık sürekli periyoda sahip aylık yağış dizileri ( $m$ boyutunda) hazırlanır. Yağış eksikliğinin farklı su kaynaklarına etkisi dikkate alınarak indislerdeki değişimlerin gözleneceği 3, 6, 12, 24 ve 48 aylık (i) gibi farklı zaman dilimleri belirlenir. $\mathrm{Bu}$ zaman dilimleri yağıştaki eksikliğin kullanılabilir su kaynaklarına olan etkisinin ne kadar sürede hissedilebileceği gibi sübjektif bir mantığa göre seçilmiştir. Örneğin herhangi bir ayda yağışta meydana gelen azalma toprak nemine hemen etki edebilirken, yeraltı sularının ve nehirlerin bundan etkilenmesi daha uzun süreli bir zaman dilimi içinde gerçekleşir. Her zaman dilimindeki veri dizileri kayan bir özellikte olup o ayın indis değeri önceki (i) ayları değerlerine göre belirlenir. Daha sonra her veri setine Gamma dağılımı uydurulur ve böylece gözlenmiş yağış olasılıkları tanımlanır.

Gamma dağılımı, klimatolojik zaman serilerine en uygun dağılımdır. Gamma dağılımı, dağılım frekansı veya olasılık yoğunluk fonksiyonu ile tanımlanmaktadır (Thom, 1958).

$$
g(x)=\frac{1}{\beta^{\mathrm{a}} T(a)} x^{\mathrm{a}-1} e^{-x / \beta}
$$

Formül 2'de kullanılan değerlerden:

$$
\begin{array}{ll}
\beta>0, & \beta \text { ölçek parametresini, } \\
a>0, & a \text { şekil parametresini, } \\
x>0, & x \text { yağış miktarını ve } \\
T(\text { a) }, & \text { ise gamma fonksiyonunu ifade etmektedir. }
\end{array}
$$

Gamma olasıllk yoğunluk fonksiyonunun alfa ve beta parametrelerinin tahmininde maksimum olasılık çözümleri $a$ ve $\beta$ tahmininde kullanılır.

$a=\frac{1}{4 A}\left(1+\sqrt{1 \frac{4 A}{3}}\right)$ ve $\beta=\frac{\bar{x}}{a}$ olarak tanımlanır.

Formül 3'teki ise Formül 4'ten elde edilir.

$$
A=\operatorname{In}(\bar{x})-\frac{\sum \operatorname{In}(x)}{n}
$$

Şeklinde hazırlanmış denklemle hesaplanmakta olup Formül 4'teki denklemde n, yağış gözlemlerinin sayısını ifade etmektedir. $\mathrm{Bu}$ parametreler hesaplandıktan sonra herhangi bir istasyonun bir ay ya da diğer zaman ölçekleri içerisinde gözlenen yağış değerinin kümülatif olasılık dağılım fonksiyonu Formül 5'teki şekliyle tanımlanmaktadır:

$$
G(x)=\int_{0}^{x} g(x) d x=\frac{1}{\beta^{a} T(\hat{a})} \int_{0}^{x} x^{a-1} e^{-x / \beta} d x
$$

Gamma fonksiyonu $\mathrm{x}=0$ için tanımsızdır ve yağış dağılımı sıfır değerini içerebilmektedir. Buna göre kümülatif olasılık değeri Formül 6'daki gibi oluşur:

$$
H(x)=q+(1-q) G(x)
$$

Bu eşitlikteki , sıfırı (0) yani yağışların bulunmamasını ifade eder. Eğer ki "m" zaman serisi içerisindeki 0 (sıfır) değerini ifade etmek için kullanılırsa " $\mathrm{q}=\mathrm{m} / \mathrm{n}$ " şeklinde tanımlanabilir.

Kümülatif olasılık değeri olan H(x), ortalaması sıfir (0) ve varyans değeri ise bir (1) ile standart rastgele değerli $\mathrm{Z}$ değerine dönüştürülür. $\mathrm{H}(\mathrm{x})$ bir SYİ değeridir. Bu durum Panofsky \& Brier (1958) tarafından tanımlanan formun dağılımının bir değişim olarak yeni bir dağılıma dönüşümü için gerekli özelliktir. SYİ değerlerinin normalize edilmesi, yağışın belirli zaman ölçeklerinde alandaki değișikliklerinin fark edilmesini ve bu değişiklerin yorumlanmasını sağlamaktadır (McKee vd. 1993; Guttman, 1999; Kömüşçü vd. 2002; Sırdaş, 2002; Pamuk vd. 2004; Kiymaz vd. 2011; Yetmen, 2013).

Ayrıca SYİ hesaplamasında bazı bilgisayar programları geliştirilmiştir. SYİ değerleri, "SPI SL 6.exe” bilgisayar programı ile hesaplanmaktadır. Programın giriş dosyası için notepad dosyasında serilerin düzenlenmesi gerekmektedir. Bunun için komut satırına sırasıyla yıl, ay ve yağış miktarları yazılır. Sonrasında istenilen periyotlara göre program çalıştırılıp veri çıktısı elde edilir (WMO, 2012).

\subsection{Gidișler Analizi}

Kuraklık analizinde yağış verilerinin ortalamadan çıkartılıp daha sonra standart sapmaya bölünüp standardize edilmesiyle nemlilik ve kuraklık değerleri elde edilir (Formül 1). Şekil 5'te görüldüğü gibi elde edilen değerlerin $X_{0}$ '’n üstünde kaldığı dönemler nemli dönemleri (pozitif dönem), $\mathrm{X}_{0}$ '’n altında kaldığı “ $M_{1}, M_{2} \ldots . . M_{\mathrm{j}}$ ” dönemler ise kurak dönemleri (negatif dönem) 
ifade etmektedir. Yani negatif gidişler kurak dönemlere karşıllık gelir. Kurak dönemlerdeki negatif gidiş uzunluğu " $L_{1}, L_{2} \ldots \ldots$, $L_{j}$ " kuraklığın süresini (periyodunu) ifade etmektedir (Yevjevich, 1967; Sırdaş, 2002: 63; Sırdaş ve Şen, 2003: 99).

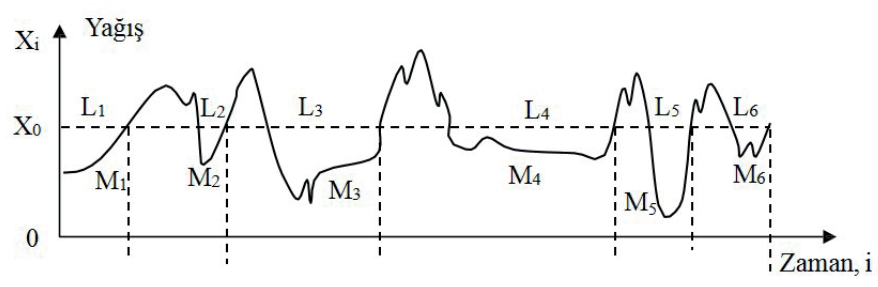

Şekil 5: Nemli ve kurak gidişler $\left(M_{\mathrm{j}}\right.$ : Kuraklık Genliği; $L_{\mathrm{i}}$ : Kuraklık Periyodu).

Figure 5: Humid and arid flows (Mj: Drought amplitude; Li: Drought period).

Kuraklık genliği, Formül 7'deki eşitlikle elde edilir.

$$
M_{j}=\sum_{i=t}^{m}\left|X_{0}-x_{1}\right|
$$

Eşitlikteki $\mathrm{X}_{0}$, SYİ'deki kuraklık kesim seviyesini, $\mathrm{X}_{1}$ ise, başta tanımlanan standartlaştırılmış seridir.

Kuraklık şiddeti $\left(l_{\mathrm{j}}\right)$ ise, kuraklık genliğinin $\left(M_{\mathrm{j}}\right)$ kuraklık süresine $\left(L_{\mathrm{j}}\right)$ bölünmesiyle elde edilir. Bu durum Formül 8 eşitliği ifade edilir (Sırdaş, 2002: 64; Sırdaş ve Şen, 2003: 99):

$$
I_{J}=\frac{M_{j}}{L_{j}}
$$

\section{BULGULAR}

Bu çalışmada 1975-2019 yağış verileri kullanılarak SYİ yöntemiyle araştırma sahasındaki istasyonların kuraklık durumları incelenmiştir. Sahadaki istasyonların 1975-2019 yıllarını kapsayan ortalama yağış miktarları Siverek'te 569,7 mm; Şanlıurfa merkezde 447,7; Birecik'te 352,2 mm; Ceylanpınar'da 287,5 mm; Akçakale'de ise 279,2 mm'dir. Bu yağış değerlerinden yola çıkarak özellikle güneydeki istasyonların daha kurak olduğu söylenebilir. Siverek dışında sahadaki tüm istasyonların yağış ortalamasının $500 \mathrm{~mm}$ 'nin altında olması, bu sahaların kurak ve yarı kurak özelliğe sahip olduğu gerçeğini ortaya koymaktadır. Araştırma sahası ile ilgili hazırlanmış benzer çalışmalarda da (Türkeş, 1990; Çiçek, 1995; Kızılelma ve Karabulut, 2011; Bölük, 2016; Gümüş, vd.,
2016; Yılmaz ve Çiçek, 2016; Yetmen, 2017; Aydın vd., 2019; İrcan, 2020) sahanın kurak-yarı kurak özelliği açıkça görülmektedir.

Araştırma sahası gibi kurak-yarı kurak iklim özelliğine sahip sahalarda yağış değişkenliğinin çok fazla olması, ekolojik ve ekonomik yönden kayıpların daha fazla olmasını tetikleyebilmektedir (Shadeed ve Masri, 2007). Araştırma sahasındaki istasyonların 1975-2019 yılları arasındaki yağış değişkenlik katsayılarının (Ceylanpınar \%35,1; Akçakale \%34,1; Şanlıurfa merkez \%30,7; Birecik \%28,2; Siverek \%27,6) \%25'in üzerinde olması, kuraklıktan etkilenebilirliğini arttırarak riskli bir konumda bulunmasına neden olmuştur.

Yağış verileri kullanılarak, SYİ metoduna göre meteorolojik kuraklık durumları incelenen bu çalışma, 12 aylık zaman (yıllık) serisine göre hazırlanmıştır. Yağışın zamana göre değişimi Şekil $7,9,11,13$ ve 15 'de verilmiştir. Kuraklığın süresindeki ve sıklığındaki artışın daha iyi anlaşılması için zaman serisi 2 döneme (1975-1997 dönemi ile 1997-2019 dönemi) ayrılıp tek tek incelenmiştir. Elde edilen bulgulara göre, Şanlıurfa merkez ile Siverek istasyonunda kurak dönemlerin oranı fazla iken; Akçakale, Birecik ve Ceylanpınar istasyonlarında nemli dönemlerin oranının daha fazla olduğu tespit edilmiştir. Ayrıca sahadaki tüm istasyonlarda kuraklık süresi, şiddeti ve sıklığındaki gidişlerin son dönemlere doğru önemli oranda arttığı da tespit edilmiştir. Elde edilen sonuçların benzeri farklı zaman dilimi ve serilerinde hazırlanan diğer araştırmacıların (Kızılelma ve Karabulut, 2011; Gümüşçü vd., 2016; Yetmen vd., 2017) çalışmalarında da tespit edilmiştir. Bu durum hem çalışmanın hem de sahadaki mevcut kuraklığın tutarlılığını göstermektedir. Araştırma sahasındaki istasyonların kuraklık durumları, alt başlıklar halinde sırasıyla şu şekildedir:

\subsection{Sanlıurfa Merkez}

Şanlıurfa merkezde kurak dönemlerin $(\% 50,93)$, nemli dönemlere $(\% 49,07)$ göre daha fazla olduğu görülmektedir. Nemli ve kurak dönemlerin zaman serisindeki dağılımına bakıldığında, II. dönemdeki (1997-2019) kuraklıkların (\%30,74), I. dönemdeki (1975-1997) kuraklıklara $(\% 20,19)$ göre daha fazla olduğu tespit edilmiştir (Şekil 6).

Kuraklıkların zaman içerisinde farklılık göstermesi, kuraklık sınıflarının dağılışını da etkilemiştir. I. dönemde aşırı kurak koşullar görülmezken, II. dönemde aşırı kuraklar \%8,43 oranına sahiptir. Ayrıca I. dönemde normale yakın kuraklık (hafif kurak) koşulları $(\% 91,74)$ yüksek iken, II. dönemde normale yakın 


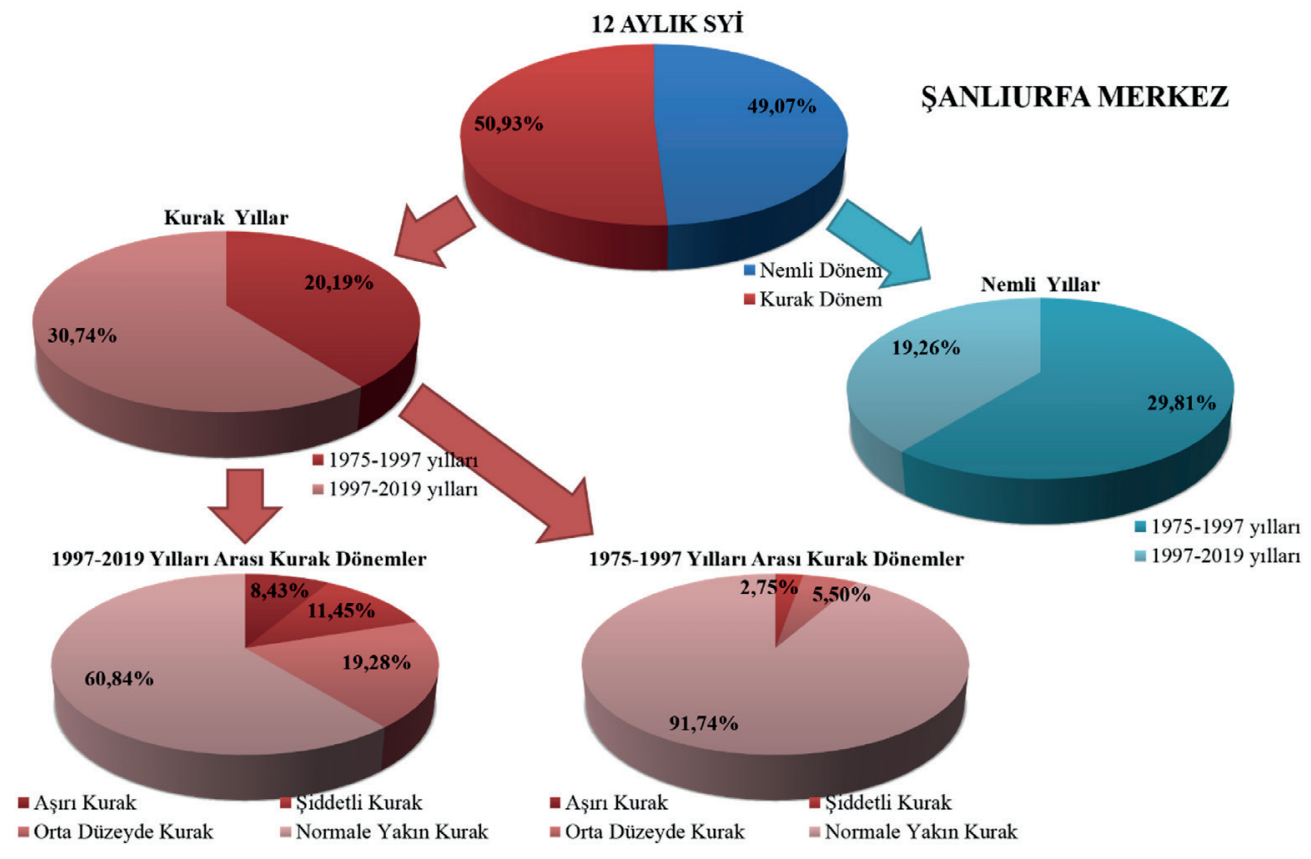

Şekil 6: Şanlıurfa merkez istasyonun yıllık SYì dağılımı.

Figure 6: Annual SPI distribution of Şanlıurfa central station.

kuraklık $(\% 60,84)$ az olup, aşırı $(\% 8,43)$, şiddetli $(\% 11,45)$ ve orta düzeyde kuraklık $(\% 19,28)$ koşulları yüksektir (Şekil 6).

I. ve II. Dönemdeki kuraklıkların dağılımı şu şekildedir:

I. Dönemde; şiddetli kuraklık \%2,75; orta düzeyde kuraklık $\% 5,50$ ve normale yakın sinıftaki kuraklık \%91,74'tür. II. Dönemde; aşırı kuraklık \%8,43; şiddetli kuraklık \%11,45; orta düzeyde kuraklık \%19,28 ve normale yakın sinıftaki kuraklık \%60,84'tür (Şekil 6).

Kuraklıkların süresine bakıldığında II. Dönemde (19972019) yaşanan kuraklıkların süresinin ve sıklığının daha fazla olduğu tespit edilmiştir. Kurak dönemlerin süresi sırasıyla şu şekildedir:

Ocak-Kasım 1975 (11 ay); Ekim-Aralık 1977 (3 ay); Mayıs 1978 - Ekim 1979 (18 ay); Kasım 1982 - Ocak 1983 (3 ay); Nisan-Aralık 1984 (9 ay); Mayıs-Ekim 1987 (5 ay); Nisan 1989-Kasım 1991 (32 ay); Aralık 1992-Mart 1993 (4 ay); Mayıs 1894-Eylül 1994 (5 ay); Şubat-Mayıs 1995 (4 ay); Ekim 1995 Ocak 1996 (4 ay); Mart-Ekim 1997 (8 ay); Aralık 1998-Nisan 2001 (29 ay); Şubat 2005-Kasım 2009 (58 ay); Mart 2010-Aralık 2011 (22 ay); Aralık 2013-Aralık 2014 (12 ay); Kasım 2015-Kasım 2018 (36 ay)'dır (Şekil 7).

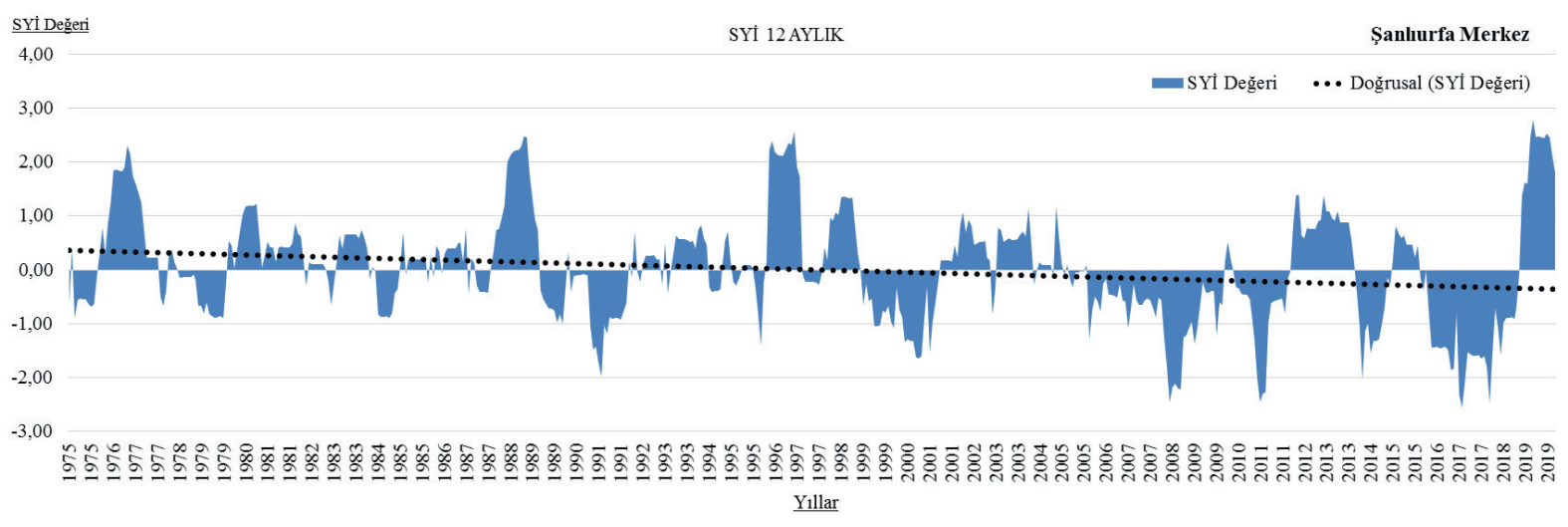

Şekil 7: Şanlıurfa merkez istasyonun yıllık SYi grafiği.

Figure 7: Annual SPI graph of Şanlıurfa central station. 
Yukarıdaki kuraklık sürelerinde de görüldüğ̈̈ gibi Şanlıurfa merkez istasyonunda II. Dönemde bulunan 1998-2001; 20052009; 2010-2011; 2015-2018 y1lları arasında kuraklık periyodundaki artışların ilk dönemin tersi bir durum sergilediği özellikle de kuraklık genliğinde aşırı ve şiddetli kuraklıkların sıklığı tespit edilmiştir (Şekil 6 ve 7).

\subsection{Akçakale}

Akçakale istasyonunda nemli dönemlerin $(\% 50,56)$, kurak dönemlere $(\% 49,44)$ oranla daha fazla olduğu tespit edilmiştir. Nemli ve kurak dönemlerin zaman serisindeki dağılımına bakıldığında, II. Dönemdeki (1997-2019) kuraklıkların (\%27,47), I. Dönemdeki (1975-1997) kuraklıklara $(\% 22,04)$ oranla daha fazla olduğu görülmektedir (Şekil 8).

I. Dönemde (1975-1997) aşırı kurak koşullar görülmezken, II. Dönemde (1997-2019) aşırı kuraklar \%7,43 oranına sahiptir. Ayrıca I. Dönemde normale yakın kuraklık koşulları $(\% 82,35)$ yüksek iken, II. Dönemde normale yakın kuraklık koşulları $(\% 67,57)$ ilk döneme göre az olup, aşırı $(\% 7,43)$, şiddetli $(\% 8,78)$ ve orta düzeyde kuraklık $(\% 16,22)$ koşulları yüksektir (Şekil 8).

I. Dönemde; şiddetli kuraklık \%5,04; orta düzeyde kuraklık $\% 12,61$ ve normale yakın sinıftaki kuraklık \%82,35'tir. II. Dönemde; aşırı kuraklık \%7,43; şiddetli kuraklık \%8,78; orta düzeyde kuraklık \%16,22 ve normale yakın sınıftaki kuraklık $\% 67,57$ 'dir (Şekil 8).

Akçakale istasyonunda I. ve II. Dönemdeki kuraklıkların dağılımı şu şekildedir:

Akçakale istasyonundaki kuraklıkların süresine bakıldığında, son yıllarda daha fazla kurak koşulların yaşandığı tespit edilmiştir. Kurak dönemlerin süresi sırasıyla şu şekildedir:

Ocak-Şubat 1975 (2 ay); Mayıs 1977-Aralık 1977 (8 ay); Kasım 1978-Ekim 1979 (12 ay); Mart-Nisan 1982 (2 ay); Kasım 1982-Ocak 1983 (3 ay); Mayıs-Kasım 1983 (7 ay); Ocak 1980-Aralık 1985 (24 ay); Nisan 1980-Kasım 1987 (20 ay); Nisan-Aralı 1989 (9 ay); Kasım 1990-Kasım 1991 (13 ay); Mart-Aralık 1992 (10 ay); Mayıs-Ekim 1994 (6 ay); Şubat 1998Ocak 2001 (36 ay); Mayıs 2005-Aralık 2009 (56 ay); Şubat 2010-Aralık 2011 (23 ay); Kasım 2013-Eylül 2014 (11 ay); Aralık 2015-Mart 2017 (16 ay)’dir (Şekil 9).

Şanlıurfa merkez istasyonunda olduğu gibi Akçakale istasyonunda II. Dönemde bulunan 1998-2001; 2005-2009; 2010-2011; 2013-2014; 2015-2017 yılları arasında kuraklık periyodundaki artışların ilk dönemin tersi bir durum sergilediği özellikle de kuraklık genliğinde aşırı ve şiddetli kuraklıkların sıklığı tespit edilmiştir (Şekil 6 ve 7).

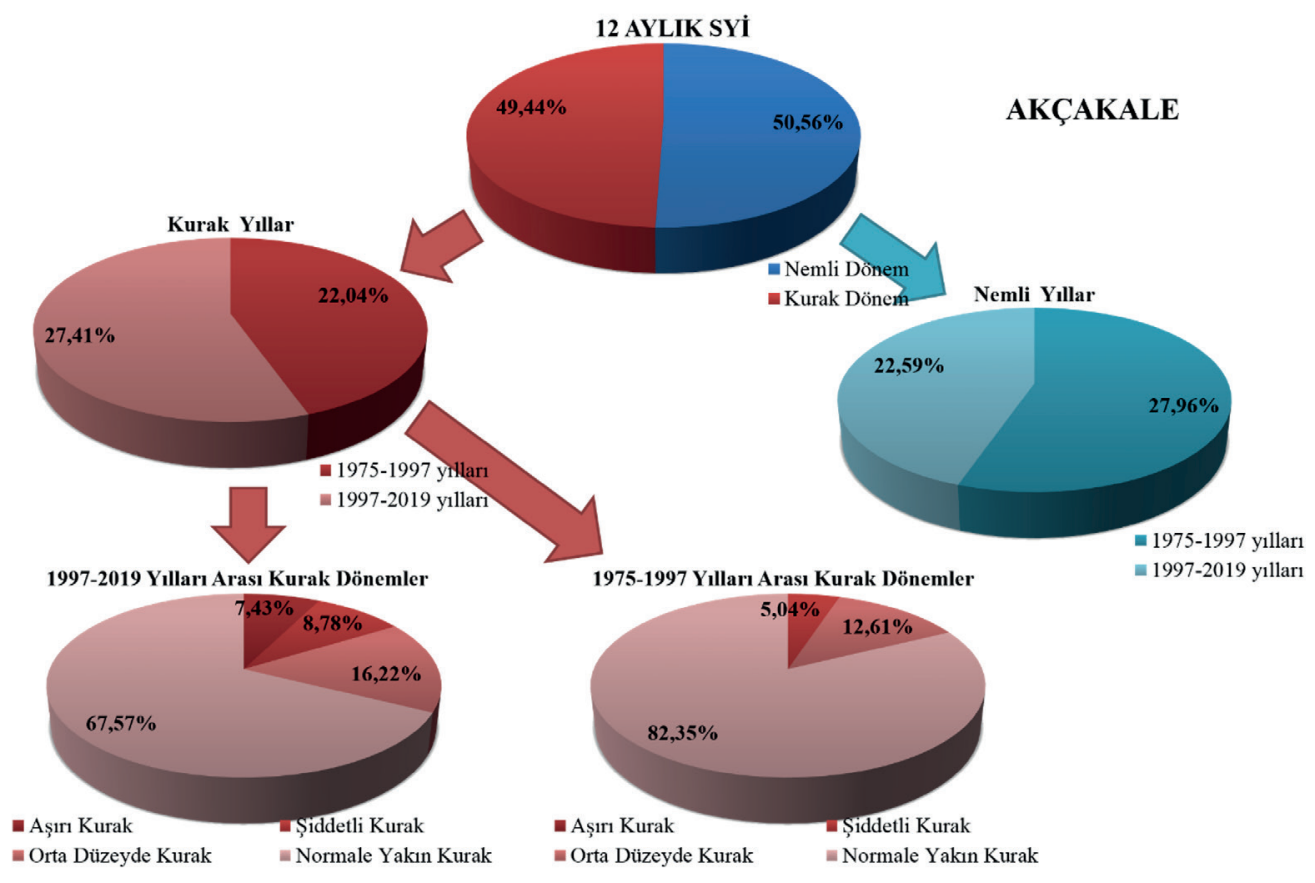

Şekil 8: Akçakale istasyonun yıllık SYi dağılımı.

Figure 8: The annual SPI distribution of Akçakale station. 


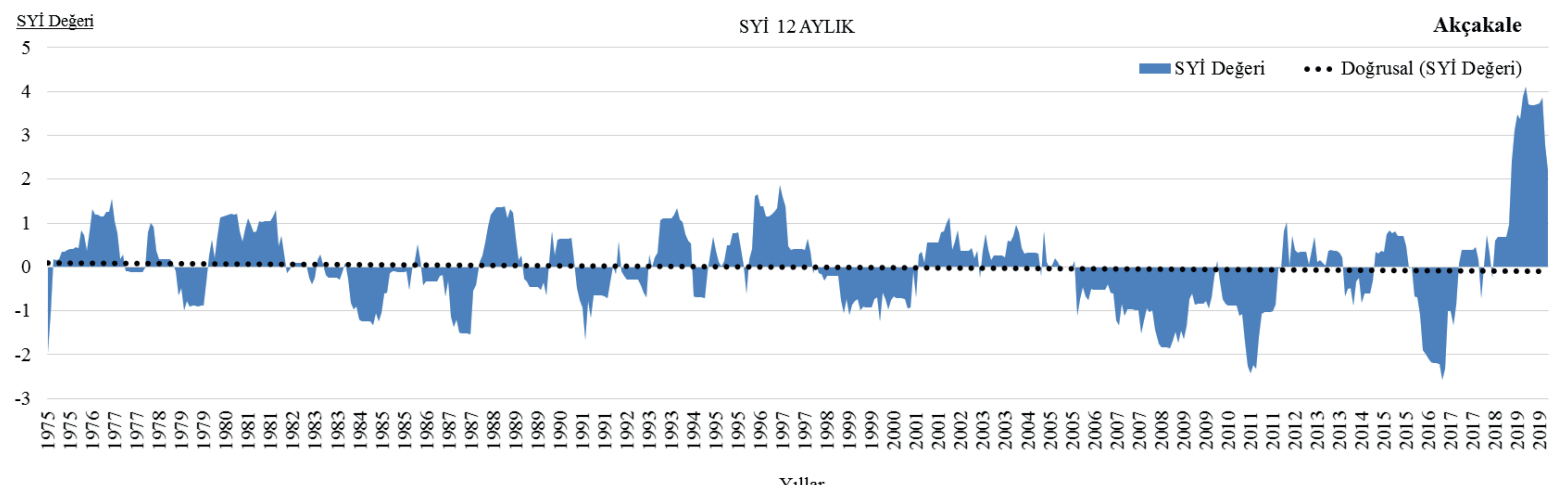

Y1llar

Şekil 9: Akçakale istasyonun yıllık SYi grafiği.

Figure 9: Annual SPI graph of Akçakale station.

\subsection{Birecik}

Akçakale istasyonunda olduğu gibi Birecik istasyonunda da nemli dönemler $(\% 50,56)$, kurak dönemlere $(\% 49,44)$ göre biraz daha fazladır. Nemli ve kurak dönemlerin zaman serisi içerindeki dağılımına bakıldığında, II. Dönemdeki kuraklıkların (\%28,33), I. Dönemdeki kuraklıklara $(\% 21,11)$ oranla daha fazla olduğu görülmektedir (Şekil 10).

I. Dönemde aşırı kuraklık koşulları görülmezken, II. Dönemde aşırı kuraklıklar \%9,80 oranına sahiptir. Ayrıca I. Dönemde normale yakın kuraklık koşulları $(\% 84,21)$ yüksek iken, II. Dönemde normale yakın kuraklık koşulları $(\% 65,36)$ ilk döneme göre az olup, aşırı $(\% 9,80)$, şiddetli $(\% 9,15)$ ve orta düzeyde kuraklık $(\% 15,69)$ koşulları yüksektir (Şekil 10).

Birecik istasyonunda I. ve II. Dönemde gerçekleşen kuraklıklarının dağılımı şu şekildedir:

I. Dönemde; şiddetli kuraklık \%7,02; orta düzeyde kuraklık $\% 8,77$ ve normale yakın sinıftaki kurakl1k \%84,21'dir. II. Dönemde; aşırı kuraklık \%9,80; şiddetli kuraklık \%9,15; orta düzeyde kuraklık \%15,69 ve normale yakın sinıftaki kuraklık $\% 65,36$ 'dır (Şekil 10).

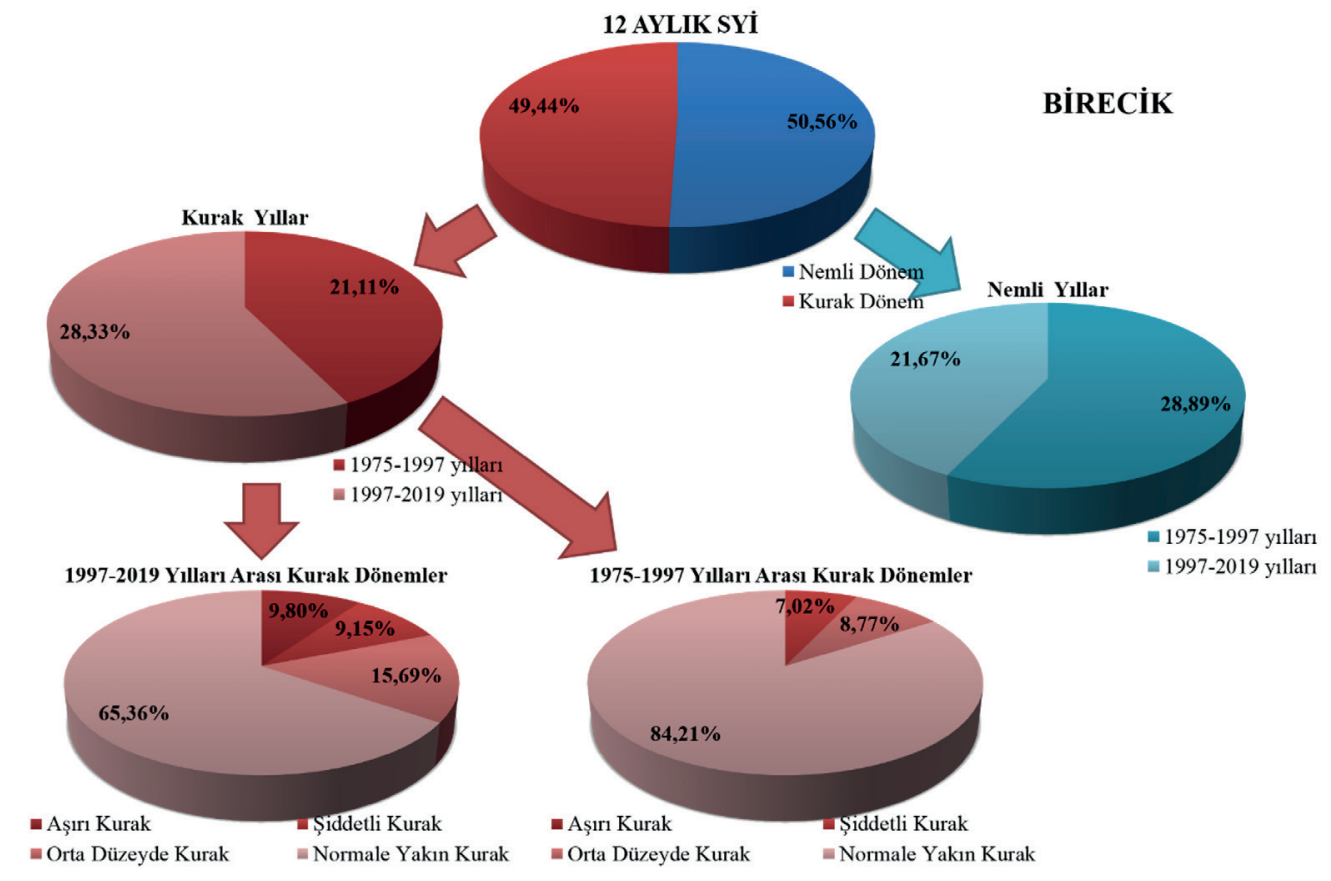

Şekil 10: Birecik istasyonun yıllık SYi dağılımı.

Figure 10: Annual SPI distribution of Birecik station. 


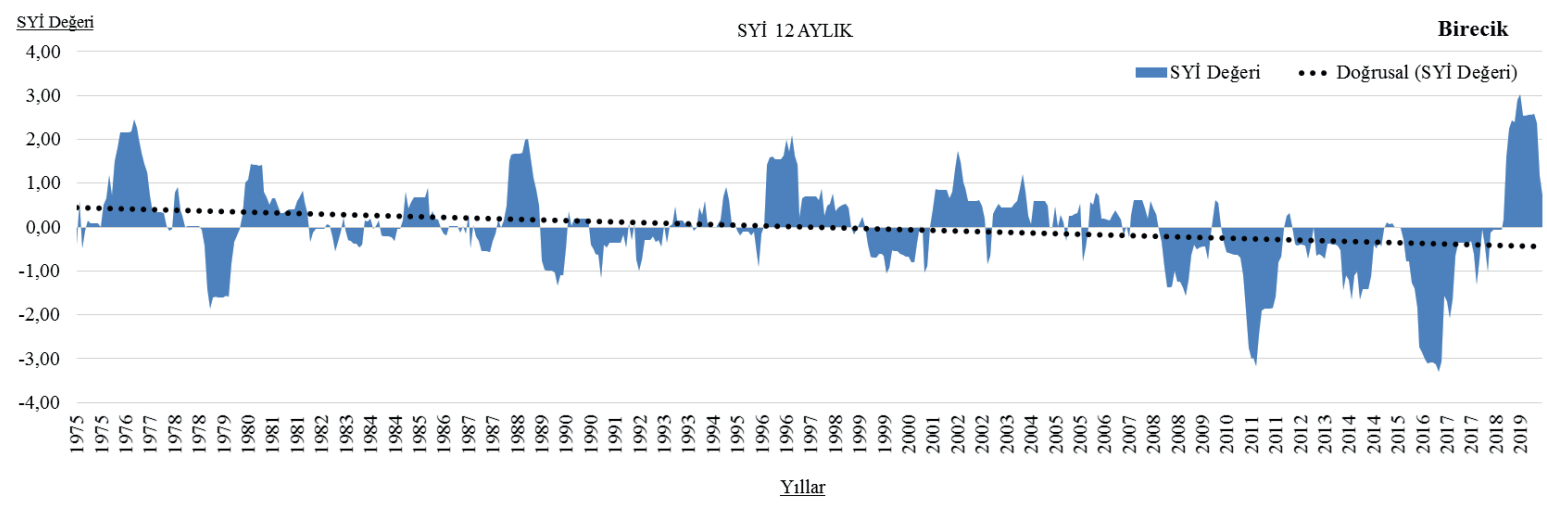

Şekil 11: Birecik istasyonun yıllık SYi grafiği.

Figure 11: Annual SPI graph of Birecik station.

Birecik istasyonunda kuraklıkların süresinin son yıllarda daha fazla olduğu tespit edilmiştir. Yaşanan kurak dönemlerin süresi sırasıyla şu şekildedir:

Mart-Nisan 1975 (2 ay); Kasım-Aralık 1977 (2 ay); Kasım 1978-Ocak 1980 (15 ay); Mart-Ağustos 1982 (6 ay); Kasım 1982-Ekim 1983 (12 ay); Mayıs-Aralık 1984 (8 ay); Mart-Mayıs 1986 (3 ay); Nisan-Kasım 1987 (8 ay); Nisan 1989-Ocak 1990 (10 ay); Ekim 1990-Aralık 1991 (15 ay); Mart 1992-Mart 1993 (12 ay); Haziran-Ağustos 1994 (3 ay); Nisan 1995-Ocak 1996 (10 ay); Ekim-Aralık 1998 (3 ay); Nisan 1999-Aralık 2020 (21 ay); Mart 2008-Ekim 2009 (20 ay); Mart 2010-Ocak 2012 (23 ay); Mayıs 2012-Şubat 2015 (34 ay); Haziran 2015-Eylül 2018 (40 ay)'dir (Şekil 11).
Birecik istasyonunda diğer istasyonlara göre II. Dönemde daha ileri zamanda bulunan 2008-2009; 2010-2017 y1lları arasında kuraklık periyodundaki artışların ilk dönemin tersi bir durum sergilediği özellikle de kuraklık genliğinde aşırı ve şiddetli kuraklıkların sıklığı tespit edilmiştir (Şekil 6 ve 7).

\subsection{Ceylanpinar}

Akçakale ve Birecik istasyonlarında olduğu gibi Ceylanpınar istasyonunda da nemli dönemler $(\% 52,78)$, kurak dönemlere $(\% 47,22)$ göre biraz daha fazladır. Nemli ve kurak dönemlerin zaman serisi içerindeki dağılımına bakıldığında, II. Dönemdeki kuraklıkların $(\% 32,22)$, I. Dönemdeki kuraklıklardan $(\% 15,00)$ daha fazla olduğu görülmektedir (Şekil 12).

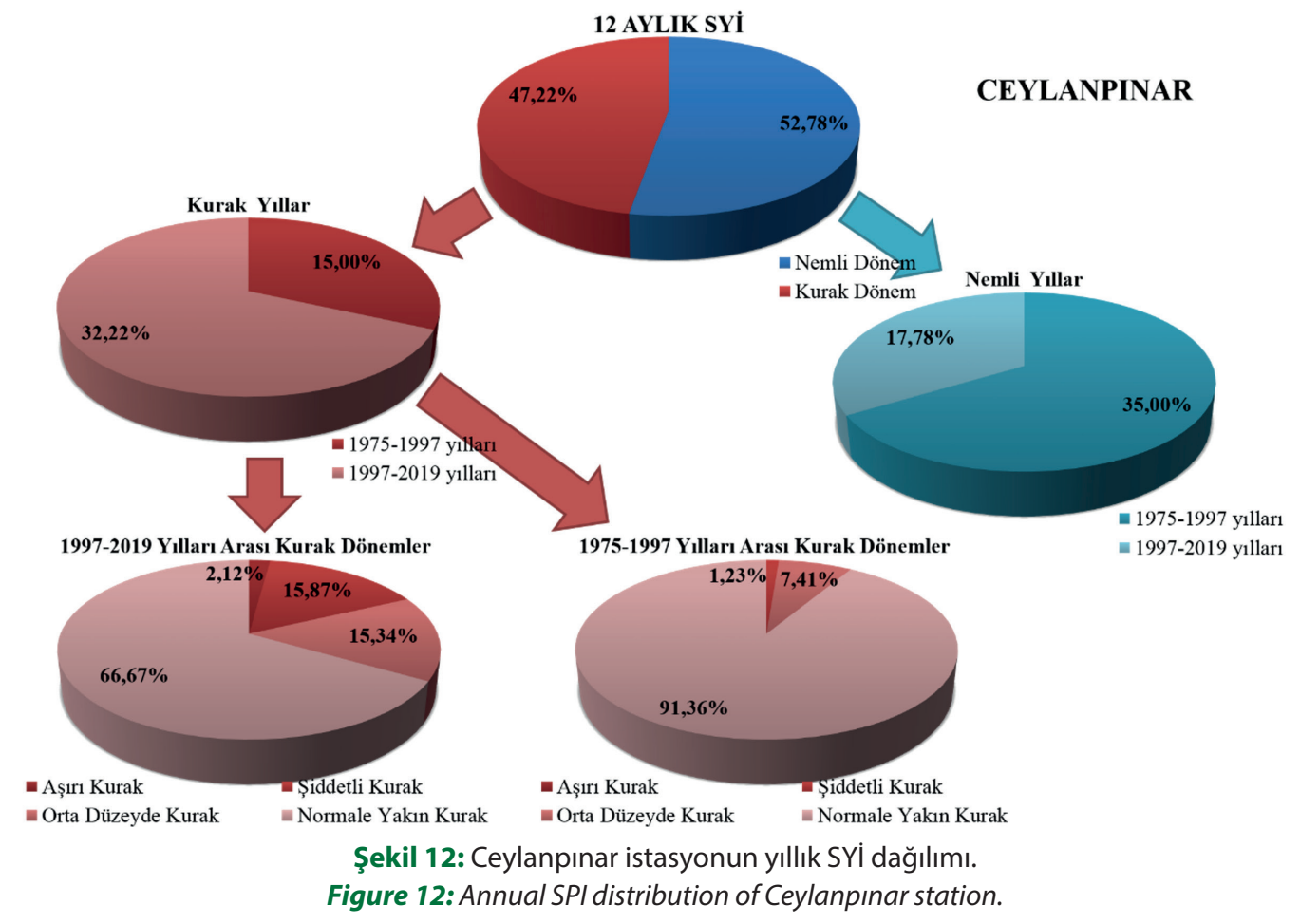


I. Dönemde aşırı kuraklık koşullar görülmezken, II. Dönemde aşırı kuraklar \%2,12 oranına sahiptir. Ayrıca I. Dönemde normale yakın kuraklık koşulları $(\% 91,36)$ çok yüksek iken, II. Dönemde normale yakın kuraklık koşulları $(\% 66,67)$ ilk döneme göre az olup, aşırı $(\% 2,12)$, şiddetli $(\% 15,87)$ ve orta düzeyde kuraklık $(\% 15,34)$ koşulları yüksektir (Şekil 12).

Ceylanpınar istasyonunun I. ve II. Dönemdeki kuraklıklarının dağılımı şu şekildedir:

I. Dönemde; şiddetli kuraklık \%1,23; orta düzeyde kuraklık $\% 7,41$ ve normale yakın sinıftaki kuraklık \%91,36'dır. II. Dönemde; aşırı kuraklık \%2,12; şiddetli kuraklık \%15,87; orta düzeyde kuraklık \%15,34 ve normale yakın sınıftaki kuraklık $\% 66,67$ 'dir (Şekil 12).

Ceylanpınar istasyonunda kuraklıkların süresinin son yıllarda daha fazla olduğu tespit edilmiştir. Yaşanan kurak dönemlerin süresi sırasıyla şu şekildedir:

Şubat-Ekim 1979 (9 ay); Şubat 1980-Mart 1985 (13 ay); Mayıs Eylül 1987 (5 ay); Nisan 1989-Ocak 1992 (34 ay); Şubat Nisan 1993 (3 ay); Kasım-Aralık 1995 (2 ay); Mart-Eylül 1997 (7 ay); Ekim 1998-Nisan 2001 (31 ay); Şubat 2002-Aralık 2002 (11 ay); Nisan 2005-Mart 2006 (12 ay); Şubat 2008-Nisan 2013 (63 ay); Ekim 2013-Ocak 2015 (16 ay); Kasım 2015-Kasım 2018 (37 ay)'dir (Şekil 13).

Yukarıdaki kuraklık sürelerinden de anlaşılacağı üzere Ceylanpınar istasyonundaki kuraklık periyodunun diğer istasyonlara göre daha kesintisiz, genliğinin ise daha büyük olduğu 2008-2013; 2015-2018 yılları arasındaki kuraklık genlik ve periyotlarından açıkça görülmektedir (Şekil 6 ve 7).

\subsection{Siverek}

Siverek istasyonunda kurak dönemlerin $(\% 50,58)$, nemli dönemlere $(\% 49,22)$ göre biraz daha fazla olduğu görülmektedir. Nemli ve kurak dönemlerin zaman serisi içerindeki dağılımına bakıldığında, I. Dönemdeki (1975-1997) kuraklıkların (\%25,58), II. Dönemdeki (1997-2019) kuraklıklara $(\% 25,00)$ oranla daha fazla olduğu tespit edilmiştir (Şekil 14).

I. Dönemde normale yakın kuraklık koşulları $(\% 77,27)$ çok yüksek iken, II. Dönemde normale yakın kuraklık koşulları $(\% 54,26)$ ilk döneme göre az olup, aşırı $(\% 3,88)$, şiddetli $(\% 11,63)$ ve orta düzeyde kuraklık $(\% 31,01)$ koşulları yüksektir (Şekil 14).

Siverek istasyonunun I. ve II. Dönemdeki kuraklıklarının dağglımı şu şekildedir:

I. Dönemde; aşırı kuraklık \%0,76; şiddetli kuraklık \%6,82; orta düzeyde kuraklık $\% 15,15$ ve normale yakın sınıftaki kuraklık \%77,27'dir. II. Dönemde; aşırı kuraklık \%3,88; şiddetli kuraklık \%11,63; orta düzeyde kuraklık \%31,01 ve normale yakın sınıftaki kuraklık \%54,26'dır (Şekil 14).

Siverek istasyonunda yaşanan kurak dönemlerin süresi sırasıyla şu şekildedir:

Mart-Aralık 1975 (10 ay); Mayıs-Aralık 1977 (8 ay); Mayıs 1978-Ekim 1979 (18 ay); Nisan-Mayıs 1981 (2 ay); Aralık 1981-Nisan 1982 (5 ay); Kasım 1982-Ocak 1985 (3 ay); Mayıs 1985-Aralık 1986 (20 ay); Haziran-Eylül 1987 (4 ay); Mart 1989-Ocak 1992 (35 ay); Nisan 1992-Mart 1993 (12 ay); MayısEylül 1994 (5 ay); Kasım 1995-Ocak 1996 (3 ay); Mart-Ekim 1997 (8 ay); Aralık 1998-Nisan 2001 (29 ay); Kasım 2002-Ocak

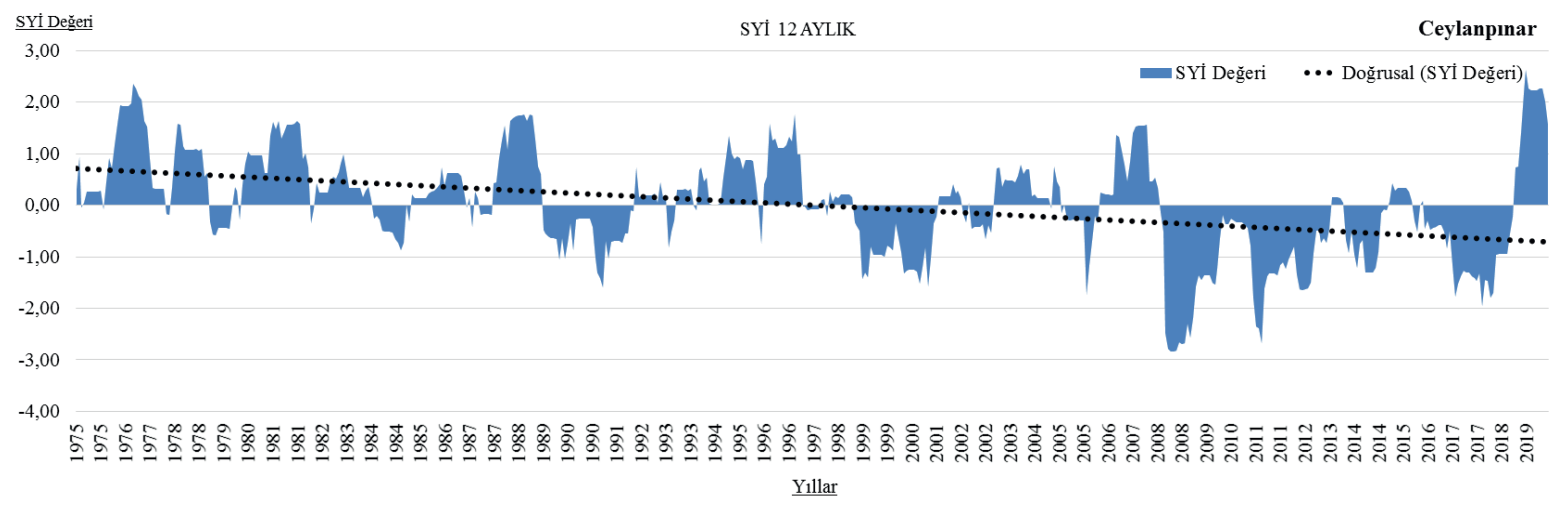

Şekil 13: Ceylanpınar istasyonun yıllık SYI grafiği.

Figure 13: Annual SPI graph of Ceylanpınar station. 


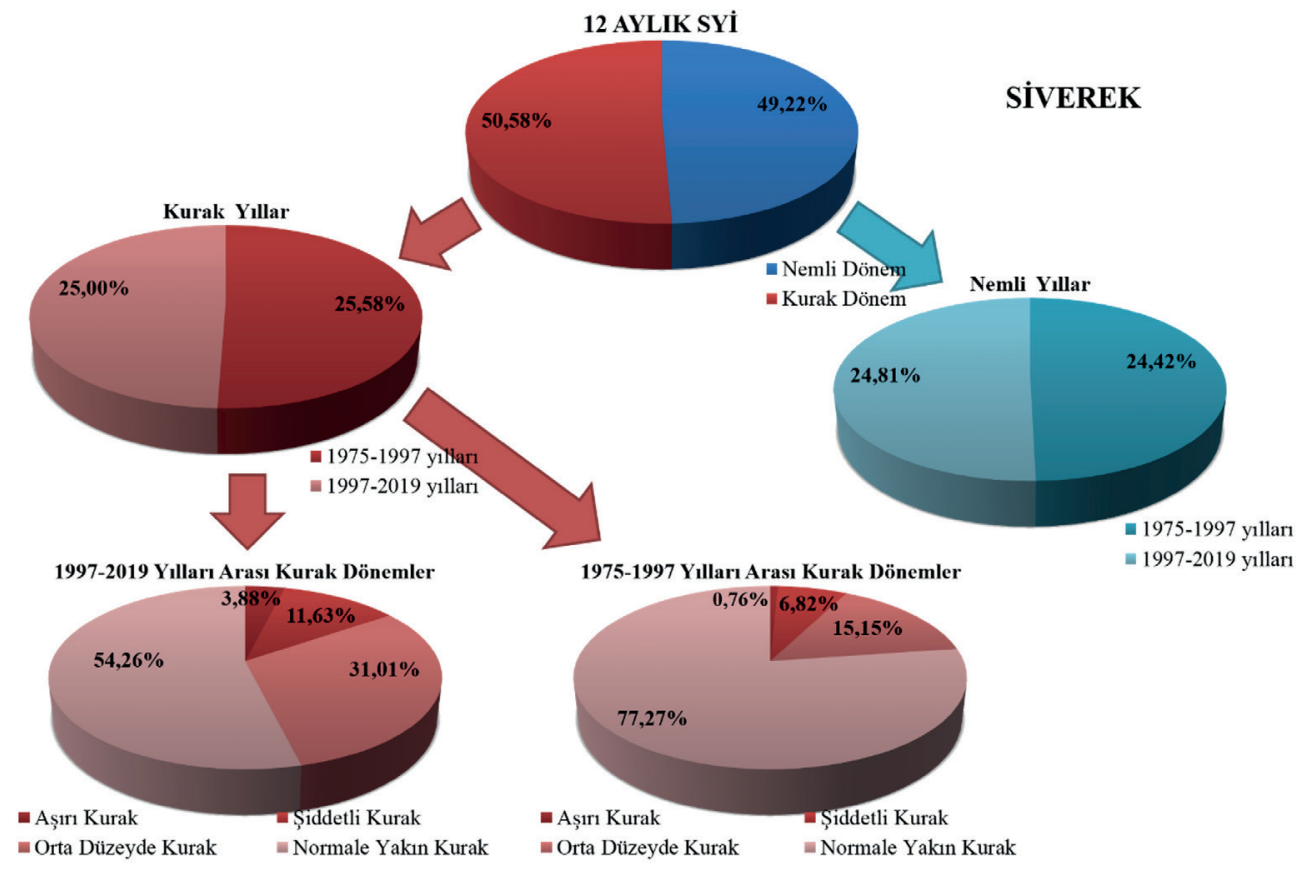

Şekil 14: Siverek istasyonun yıllık SYİ dağılımı.

Figure 14: Annual SPI distribution of Siverek station.

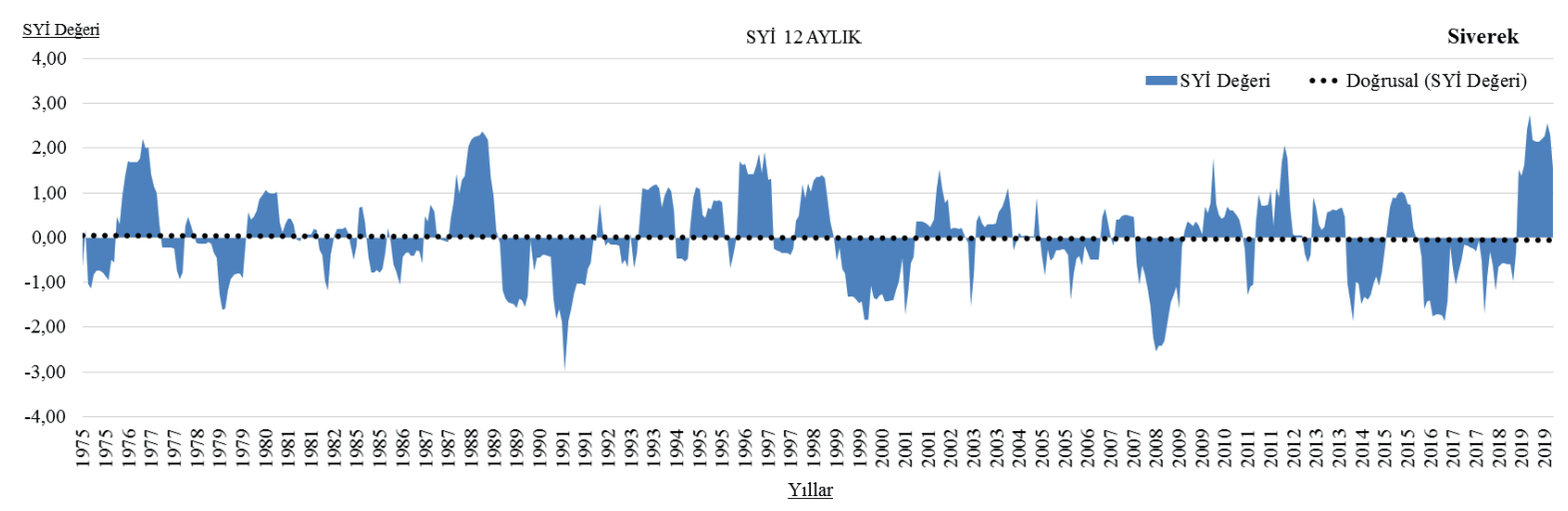

Şekil 15: Siverek istasyonun yıllık SYi grafiği.

Figure 15: Annual SPI graph of Siverek station.

2003 (3 ay); Mart-Nisan 2004 (2 ay); Ocak 2005-Eylül 2006 (21 ay); Ekim 2007-Şubat 2009 (17ay); Aralık 2010-Mart 2011 (4 ay); Eylül-Kasım 2012 (3 ay); Aralık 2013-Ocak 2015 (14 ay); Ocak 2016-Kasım 2018 (35 ay)'dir (Şekil 15).

Siverek istasyonunda kurak dönemlerin yağışlara daha anlamlı cevaplar vererek nemli ve kurak dönemlerin birbirini takip ettiği tespit edilmiştir (Şekil 14 ve 15).

\section{SONUÇ VE ÖNERILER}

Hazırlanan bu çalışmada, farklı zaman dilimlerindeki yağış azlığını ve bunun yeraltı suyu, toprak nemi, akarsu gibi su birikim hazneleri üzerindeki etkisini belirlemek için geliştirilmiş Standartlaştırılmış Yağış İndisi, kullanılarak Şanlıurfa ilindeki istasyonların kuraklık durumları analiz edilmiştir. Yapılan analizde 12 aylık zaman periyodu kullanılmıştır.

Yapılan analizin sonuçlarına göre, Şanlıurfa merkez ve Siverek istasyonlarındaki kurak dönemler nemli dönemlerden fazla iken, Akçakale, Birecik ve Ceylanpınar istasyonlarında ise nemli dönemler kurak dönemlerden daha fazladır. İstasyonlar arasındaki kurak-nemli dönem oranın farklılık göstermesi SYI'nin başlangıç yılındaki verilerinin çıktı alınan değerler üzerinde etkili olmasından kaynaklanmaktadır. Ayrıca, her istasyondaki yağışın zaman ölçeğindeki değişkenliğinin ve 
rejiminin farklı olması, yapılan analizlerde farklı veri çıktısının elde edilmesine neden olmuştur. Burada dikkat edilmesi gereken durum, 45 ylllık dönem içerisinde ilk döneme kıyasla ikinci dönemde kuraklık şiddetinin, süresinin ve sıklığının Siverek istasyonu dışındaki tüm istasyonlarda artmış olmasıdır. $\mathrm{Bu}$ durum, Siverek istasyonun araştırma sahasındaki diğer istasyonlara göre daha nemli (İrcan, 2020) olmasindan kaynaklanmaktadır.

Elde edilen sonuçların bir benzeri, farklı zaman dilimi ve farklı zaman serilerinde hazırlanmış diğer çalışmaların sonuçlarıyla da benzerlik göstererek hem çalışmanın hem de sahadaki mevcut kuraklığın tutarlılığını göstermektedir. Son 2 y1l hariç diğer önceki 10 y1l içerisinde görülen kuraklıklar sahadaki yağış azlığından kaynaklanmaktadır. Özellikle araştırma sahasında 12 aylık zaman periyodunun uygulanası ve Siverek dışındaki diğer tüm istasyonların yağış değişim katsayılarının yüksek olması, başlayan kurak ve nemli dönemlerin yavaş hareket ederek uzun dönemler içerisinde yaşanmasına neden olmuştur. Siverek istasyonunda ise yağış değerlerinin ve standart sapmasının yüksek, yağış değişim katsayısının ise düşük olması, SYİ'deki kurak ve nemli dönemlere ardalanmalı salınım göstermesini sağlamıştır.

Kurak dönemlerin son yıllara doğru artması, kuraklıkla alakalı çok yönlü eylem planlarının gerekliliğini ortaya koymaktadır. Bu konuda öncelikle araştırma sahasının fiziki coğrafya koşulları (iklimi, hidrografyası, hidroklimatolojisi) çok iyi incelenip, bilinen tüm yönleriyle sürdürülebilir ve uygulanabilir çalışmalar planlanmalıdır.

Mevcut su kaynağının potansiyeli yörenin fiziki coğrafya değişkenlerine uygun olarak hesaplanıp bunun planlaması doğru şekilde yapılmalıdır (Aydın vd., 2017:17). Araştırma sahasının tarımsal açıdan önemi (Sahadaki verimli ovaların varlığı), aşırı kurak dönemlerin ya da ani yağışlara bağlı olarak verimli tarımsal alanlardan alınan tarımsal ürünün miktarı ve kalitesini de olumsuz bir şekilde etkileyecektir. Bu yüzden, tarımsal faaliyetin kuraklıktan en az etkilenmesi için düzenli ve sürdürülebilir hidroklimatik planlamaların yapılması gerektiğini ortaya koymaktadır. Özellikle Şanlıurfa'nın iklimi ve kuraklık özelliğiyle alakalı hazırlanan çalışmalara önem verilip, bu ve benzeri çalışmaların sonuçları göz önünde bulundurularak ileriye yönelik politikalar üretilip eyleme geçirilmelidir.

Teşekkür: Yazarlar, bu çalışmayı okuyarak değerlendirmelerde bulunan Prof. Dr. Sevinç Asılhan-Sırdaş’a (İTÜ, Uçak ve Uzay Bilimleri Fakültesi, Meteoroloji Mühendisliği Bölümü) teşekkür eder.
Hakem Değerlendirmesi: Dış bağımsız.

Çıkar Çatışması: Yazarlar çıkar çatışması bildirmemiştir.

Finansal Destek: Yazarlar bu çalışma için finansal destek almadığını beyan etmiştir.

Peer-review: Externally peer-reviewed.

Conflict of Interest: The authors have no conflict of interest to declare.

Grant Support: The authors declared that this study has received no financial support

\section{KAYNAKÇA/REFERENCES}

Aydın, O., Ünaldı, Ü. E., Duman, N., Çiçek, İ. ve Türkoğlu, N. (2017). Türkiye'de su kıtllğının mekânsal ölçekte değerlendirilmesi. Türk Coğrafya Dergisi, (68), 11-18.

Aydın, S., Şimşek, M., Çetinkaya, G. ve Öztürk, M. Z. (2019). "Erinç Yağış Etkinlik İndisi'ne göre belirlenen Türkiye iklim bölgelerinin rejim karakteristikleri”. B. Gönençgil, T. A. Ertek, İ. Akova, E. Elbaşı (Ed.). 1. İstanbul Uluslararası Coğrafya Kongresi Bildiri Kitabl, 20-22 Haziran 2019, (ss. 752-760). İstanbul: İstanbul Üniversitesi.

Bölük, E. (2016). Erinç iklim sinfflandırmasina göre Türkiye iklimi. Ankara: Meteoroloji Genel Müdürlüğü.

Chen, S. T., Kuo, C. C. \& Yu, P. S. (2009). Historical trends and variability of meteorological droughts in Taiwan. Hydrological Sciences Journal, 54(3), 430-441.

Çiçek, İ. (1995). Türkiye'de kurak dönemin yayıllșı ve süresi (Thornthwaite yöntemine göre). Ankara Üniversitesi, Türkiye Coğrafyası Araștırma ve Uygulama Merkezi Dergisi, (4), 77-101.

Çiçek, İ. ve Ataol M. (2009). Türkiye'nin su potansiyelinin belirlenmesinde yeni bir yaklaşım. Coğrafi Bilimler Dergisi, 7, 5164.

Di Lena, B., Vergni, L., Antenucci, F., Todisco, F. \& Mannocchi, F. (2013). Analysis of drought in the region of Abruzzo (Central Italy) by the Standardized Precipitation Index. Theoretical and Applied Climatology, 115, 41-52.

Dinç, N., Aydinşakir, K., Işık, M. ve Büyüktaş, D., (2016). Standartlaştırılmış Yağış İndeksi (SPI) yöntemi ile Antalya ili kuraklık analizi. Research Article, 33(2), 279-298.

Edwards, D. C. (1997). Characteristics of 20th century drought in the United States at multiple time scales. Colorado State University, Thesis, Fort Collins, Colorado.

Edwards D C \& McKee T B (1997). Characteristics of 20th century drought in the United States at multiple time scales. Climatology Report Number 97-2, Colorado State University, Fort Collins, Colorado

Erlat, E. (2002). Türkiye'de yağış anomalileri ve Kuzey Atlantik Salınımı ile ilişkisi. Prof. Dr. Strrı Erinç Anısına Klimatoloji Çalıştayl, 11-13 Nisan 2002, (ss.193-210). Ege Üniversitesi, İzmir.

Fathabadi, A., Gholami, H., Salajeghe, A., Azanivand, H. \& Khosravi, H. (2009). Drought forecasting using neural network and stochastic models. Advances in Natural and Applied Sciences, 3(2), 137-146. 
Gocic, M. \& Trajkovic S. (2014). Spatiotemporal characteristics of drought in Serbia. Journal of Hydrology, 510, 110-123.

Guhathakurta P., Menon P., Inkane P. M., Krishnan U. \& Sable S. T. (2017). Trends and variability of meteorological drought over the districts of india using Standardized Precipitation İndex, Journal of Earth System Science, 126 (120), 1-18.

Guttman, N. B. (1999). Accepting the Standardized Precipitation Index: A calculation algoritm. Journal of the American Water Resources Association, 35 (2), 311-322.

Gümüş, V., Başak, A. ve Oruç, N. (2016). Standartlaştırılmış Yağış İndeksi (SYİ) Yöntemi ile Şanlıurfa istasyonunun kuraklık analizi. Harran Üniversitesi Mühendislik Dergisi, (01), 36-44.

Hızarcıoğlu, S. (2010). Kuzey Atlantik Salınımının hidrolojik değişkenler üzerindeki etkisi. Atatürk Üniversitesi Fen Bilimleri Enstitüsü, Yüksek Lisans Tezi, Erzurum.

Hurrell, J. W. \& Van Loon, H. (1997). Decadal varıations in climate associated with the North Atlantic Oscillation. Climatic Change, 36: $301-326$.

Hurrell, J.W., Kushnir, Y., Ottersen, G. \& Visbeck, M. (2003). The North Atlantic Oscillation: Climatic Significance and Environmental Impact. Geophysical Monograph, 134, 1-35.

Ilgar, R. (2010). Çanakkale'de kuraklık durumu ve eğilimlerinin Standartlaştırılmış Yağış İndisi ile belirlenmesi. Marmara Coğrafya Dergisi, (22), 183-204.

İrcan, M. R. (2020). Şanlıurfa'nın iklim özellikleri ve kuraklık analizi. Çankırı Karatekin Üniversitesi Sosyal Bilimler Enstitüsü, Yüksek Lisans Tezi, Çankırı.

Karaer, M. ve Gültaş, H. T. (2018). Kuraklık oluşumunun Bilecik İli’nde Standartlaştırılmış Yağış İndeksi yöntemi kullanılarak değerlendirilmesi. Süleyman Demirel Üniversitesi Ziraat Fakültesi Dergisi - I. Uluslararası Tarımsal Yapılar ve Sulama Kongresi Özel Sayısi: 303-308.

Kıymaz, S., Güneş, V. ve Asar, M. (2011). Standartlaştırılmış Yağış İndeksi ile Seyfe Gölü'nün kurak dönemlerinin belirlenmesi. Gaziosmanpaşa Üniversitesi Ziraat Fakültesi Dergisi, 28(1), 91-102.

Kızılelma, Y. ve Karabulut, M. (2011). Şanlıurfa İli'nde Kuraklık Analizi. I. Ulusal Akdeniz Orman ve Çevre Sempozyumu, 26-28 Ekim 2011, (ss. 1141-1151). Kahramanmaraş Sütçüİmam Üniversitesi: Kahramanmaraş.

Kim, D. W., Byun, H. R. \& Choi, K. S. (2009). Evaluation, modification, and application of the effective drought index to 200-year drought climatology of Seoul, Korea. Journal of Hydrology, 378(1-2), 1-12.

Koçman, A. (1993). Türkiye'de yağış yetersizliğine bağlı kuraklık sorunu. Ege Coğrafya Dergisi, 7, 77-88.

Kömüşçü, A. Ü., Erkan, A. ve Turgu, E. (2002). Normalleştirilmiş Yağış Indeksi Metodu ile Türkiye'de Kuraklık Oluşumunun Coğrafik Analizi. DMİ Genel Müdürlüğü Araştırma ve Bilgi İşlem Dairesi Başkanlığı Yayını: Ankara.

Kömüşçü, A. Ü., Erkan, A., ve Turgu, E. (2003). Normalleştirilmiş Yağış İndeksi (SPI) Metodu ile Türkiye'de Kuraklık Oluşum Oranlarının Bölgesel Dağılımı. III. Atmosfer Bilimleri Sempozyumu, 19-21 Mart 2003, (ss. 268-275) İstanbul Teknik Üniversitesi: İstanbul.
Labedzki, L. (2017), Categorical forecast of precipitation anomaly using the Standardized Precipitation Index SPI, Water, 9(8), 1-14.

L1, W., Fu, R., Juarez, R. I. N. \& Fernandes, K. (2008). Observed change of the Standardized Precipitation İndex, its potential cause and implications to future climate change in the Amazon region. Philosophical Transactions of The Royal Society B, 363(1498), 1767-1772.

Liu, J. F., Zhang, X. N. \& Wang, H. M. (2013). Drought and flood distribution variation based on SPI in Nanjing, China. Applied Mechanics and Materials, 295-298, 2116-2120.

Mckee, T. B., Doesken, N. J. \& Kleist, J. (1993). The Relationship of Drought Frequency and Duration to Time Scales. 8th Conference on Applied Climatology, 17-22 January 1993, (ss.179-184) Anaheim, California.

McKee, T. B., Doesken, N. J. \& Kleist, J. (1995). Drought Monitoring With Multiple Time Scales. American Meteorological Society Proceedings of 9th. Conference on Applied Climatology, 15-20 January 1995. (ss. 233-236) American Meteorological Society, Boston.

Moreira, E. E., Paulo, A. A., Pereira, L. S. \& Mexia, J. T. (2006). Analysis of SPI drought class transitions using loglinear models. Journal of Hydrology, 331(1-2), 349-359.

Palmer, W. C. (1965). Meteorological Drought. Research Paper No. 45, Office of Climatology U.S. Weather Bureau: Washington.

Pamuk, G., Özgürel, M. ve Topçuoğlu, K. (2004). Standart yağış indisi (SPI) ile Ege bölgesinde kuraklık analizi. Ege Üniversitesi Ziraat Fakültesi Dergisi, 41(1), 99-106.

Panofsky, H. A. \& Brier, G. W. (1958). Some applications of statistics to meteorology. Pennsylvania State University: University Park, Pennsylvania.

Patel, N. R., Chopra, P. \& Dadhwal, V.K. (2007). Analyzing spatial patterns of meteorological drought using standardized precipitation index. Meteorological Applications, 14(4), 329-336.

Santos, J. F., Portela, M. M. \& Pulido-Calvo, I. (2011). Regional frequency analysis of droughts in Portugal. Water Resources Management, 25, 3537-3558.

Shadeed, S. \& Almasri, M. (2007). Statistical analysis of long-term rainfall data for a Mediterranean semi-arid region: a case study from Palestine. Included in the international conference, Sustainable Development and Management of Water in Palestine. Amman, Jordan.

Sırdaş, S. (2002). Meteorolojik kuraklık modellemesi ve Türkiye uygulamast. İstanbul Teknik Üniversitesi Fen Bilimleri Enstitüsü, Doktora Tezi, İstanbul.

Sırdaş, S. ve Şen, Z. (2003). Meteorolojik kuraklık modellemesi ve Türkiye uygulaması. ITÜ Dergisi/d Mühendislik, 2(2), 95-103.

Thom, H. C. S. (1958). A Note on the Gamma Distribution. Monthly Weather Review. 86 (4), 117-122.

Topçuoğlu, K., Mengü, G.P. ve Anaç, S. (2008). Ege Bölgesi Meteorolojik Kuraklık Analizi. 5. Dünya Su Forumu Türkiye Bölgesel Su Toplantıları-Konya Kapalı Havzası Yer altı suyu ve Kuraklık Konferansı (ss. 175-184). Devlet Su İşleri Genel Müdürlüğ̈: Konya. 
Türkeş, M. (1990). Türkiye'de kurak bölgeler ve önemli kurak yillar. İstanbul Üniversitesi Deniz Bilimleri ve Coğrafya Enstitüsü, Doktora Tezi, İstanbul.

Türkeş, M. (1999). Vulnerability of Turkey to desertification with respect to precipitation and aridity conditions, Turkish Journal of Engineering and Environmental Sciences, 23, 363-380.

Türkeş, M. ve Erlat, E. (2003). Türkiye'de Kuzey Atlantik Salınımı ile bağlantılı yağış değişiklikleri ve değişebilirliği. III. Atmosfer Bilimleri Sempozyumu, 19-21 Mart 2003, (ss. 318-333). İstanbul: İstanbul Teknik Üniversitesi.

Türkeş, M. ve Tatlı, H. (2008). Aşırı kurak ve nemli koşulların belirlenmesi için yeni bir Standartlaştırılmış Yağış İndisi (yeniSPI): Türkiye'ye uygulanması. IV. Uluslararası Atmosfer Bilimleri Sempozyumu Bildiriler Kitabı, 25-28 Mart 2008, (ss. 528-538). İstanbul.

Türkeş, M. ve Tatlı, H. (2010). Kuraklık ve yağış etkinliği indislerinin çölleşmenin belirlenmesi, nitelenmesi ve izlenmesindeki rolü. Çölleşme ile Mücadele Sempozyumu, 17-18 Haziran 2010, (ss. 245263). Çorum.
WMO (2012). Standardized Precipitation Index user guide. Geneva: World Meteorological Organization.

Yetmen, H. (2013a). Van Gölü Havzası'nın kuraklık analizi. 21. Yüzyılda Eğitim ve Toplum, 3(5): 184-198.

Yetmen, H. (2013b). Türkiye'nin kuraklık analizi. Ankara Üniversitesi Sosyal Bilimler Enstitüsü, Doktora Tezi, Ankara.

Yetmen, H. (2014). Orta Karadeniz'deki kuraklık olaylarının karakteristikleri. TÜCAUM VIII. Coğrafya Sempozyumu, (ss. 8796). Ankara, Türkiye.

Yetmen, H., Aytaç, A.S. ve Özcanlı, M. (2017). Harran Ovası'nın kuraklık analizi. Akademik Sosyal Araştırmalar Dergisi, (46), 132146.

Yevjevich, V. M. (1967). An objective approach to definitions and investigations of continental hydrologic droughts. Hydrology Papers Colorado State university Fort Collins, (23), 1-16.

Yılmaz, E. ve Çiçek, İ. (2016). Türkiye Thornthwaite iklim sinıflandirmas1. Journal of Human Sciences, 13(3), 3973-3994.

Zhang, Q., Li, J., Singh, V. P. \& Bai, Y. (2012). SPI-based evaluation of drought events in Xinjiang, China. Natural Hazards, 64, 481-492. 